\title{
EFFECT OF CO-DIGESTION OF SOURCE SEPARATED ORGANICS AND MANURE ON METHANE PRODUCTION
}

\author{
By \\ Devarshi Sevak \\ B.E. in Civil Engineering \\ Gujarat Technological University (GTU), 2017 \\ A Major Research Project \\ presented to Ryerson University \\ in partial fulfillment of the \\ requirements for the degree of \\ Master of Engineering \\ in the program of \\ Civil Engineering
}

Toronto, Ontario, Canada, 2019

C Devarshi Sevak,2019 


\section{$\underline{\text { Author's Declaration }}$}

I hereby declare that I am the sole author of this MRP. This is a true copy of the MRP, including any required final revisions, as accepted by my examiners.

I authorize Ryerson University to lend this MRP to other institutions or individuals for scholarly research.

I further authorize Ryerson University to reproduce this MRP by photocopying or by other means, in total or in part, at the request of other institutions or individuals for scholarly research.

I understand that my MRP may be made electronically available to the public. 


\title{
EFFECT OF CO-DIGESTION OF SOURCE SEPARATED ORGANICS AND MANURE ON METHANE PRODUCTION
}

Master of Engineering, 2019

By Devarshi Sevak

Department of Civil Engineering, Ryerson University

\begin{abstract}
Anaerobic co-digestion (AcoD) is more advantageous than conventional mono-digestion, because of higher gas production rate. This study was aimed to study the effect of mixture ratio in codigestion of manure and source separated organics (SSO) in mesophilic condition.

Manure and SSO at different mixture ratios of 9:1, 7:3, 5:5, 3:7, and 1:9 on a volumetric basis were used to determine the effect of the mixture ratios on methane production in biomethane potential assay (BMP). Results showed that co-digestion of SSO and manure at the ratio of 1:9 $(\mathrm{V} / \mathrm{V})$ resulted in the highest biomethane production rate of $46 \mathrm{~mL} \mathrm{CH}_{4} /$ day. In comparison, the maximum methane production rate for anaerobic digestion of manure alone was $43 \mathrm{~mL} \mathrm{CH} 4$ /day. When manure is mixed with $\mathrm{SSO}$ at a ratio of 5:5, about $15 \%$ higher cumulative methane production has been achieved. This research also verified the advantages of co-digestion over mono-digestion.
\end{abstract}

Keywords: Anaerobic Digestion, Co-digestion, Source Separated Organics (SSO), Manure 


\section{$\underline{\text { Acknowledgements }}$}

I would like to thank almighty God, for all his blessings.

I specially want to thank Dr. Elsayed Elbeshbishy for his persistent guidance, timely support, and valuable advice throughout this project. His proficiency was the key factor to understand and deal with many of the difficulties that I encountered during my project work.

I would also like to extend my gratitude to Anahita Rabii for providing me appropriate and accurate knowledge that helped me throughout the experimental work of this study.

This project would have not reached its last stage, unless the support of Ahmad Shabir Razavi, Erfan, Farokh Laqa Kakar, Frances Okoye, Raman Sharma, Suleman Khan and Umme Sharmeen Hyder. Their immense help while my training and experimental set up has facilitated completion of the project.

Lastly, I would like to thank my family and friends for their kind support. 


\section{$\underline{\text { Table of Contents }}$}

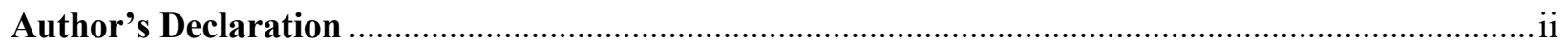

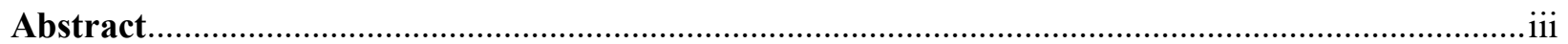

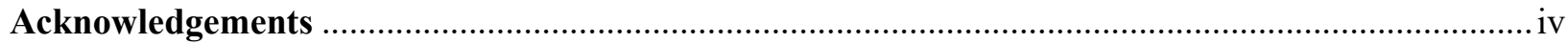

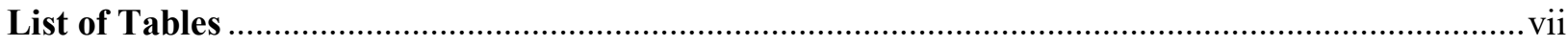

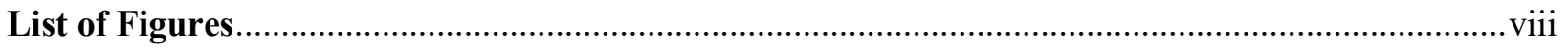

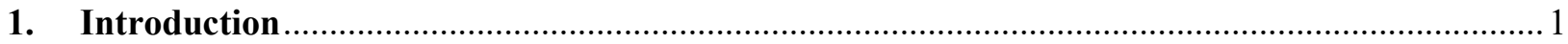

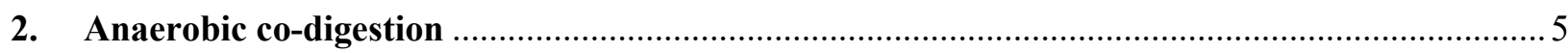

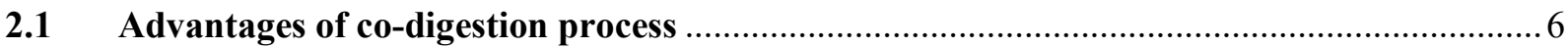

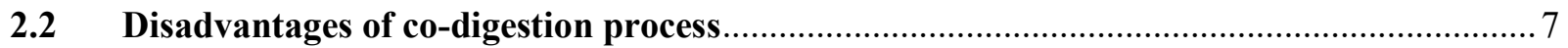

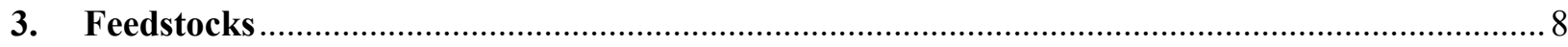

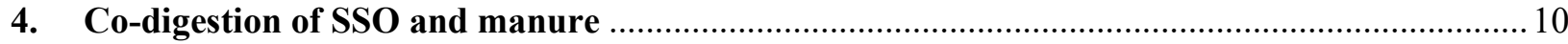

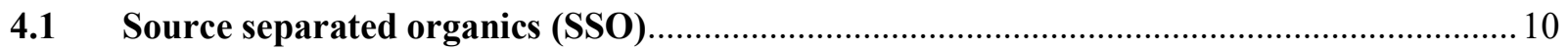

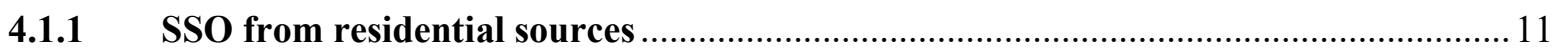

4.1.2 SSO from industrial, commercial and institutional sources ..................................... 11

4.2 Manure

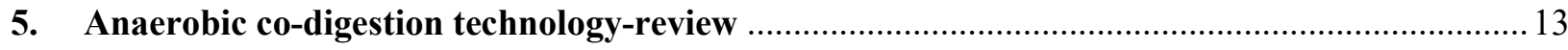

5.1 Anaerobic co-digestion of organic wastes (G. Esposito, 2012) ........................................ 13

5.2 Anaerobic digestion of dairy manure: design and process considerations (Wilkie, 2005) . 13

5.3 Biomethane potential evaluation of co-digestion of sewage sludge and organic wastes

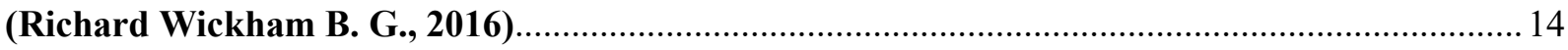

5.4 Anaerobic co-digestion of cattle slurry with maize stalk at mesophilic temperature (A.O.

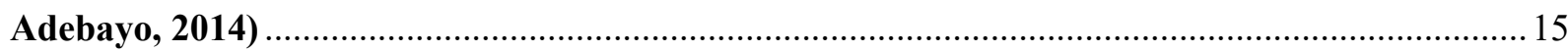

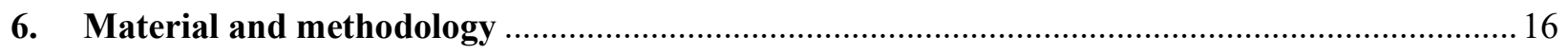

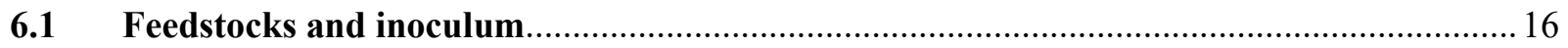

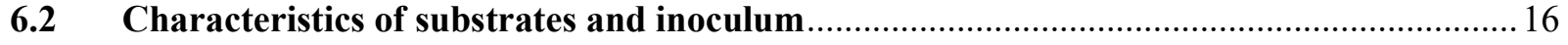




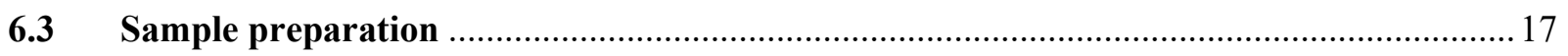

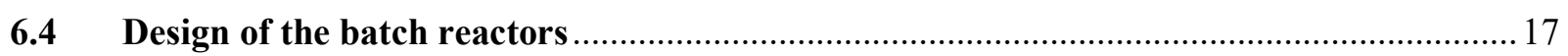

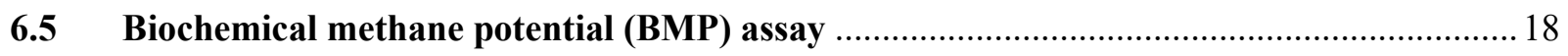

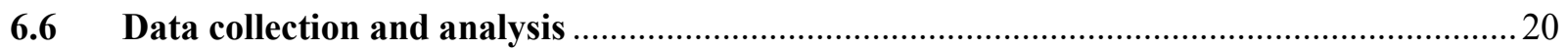

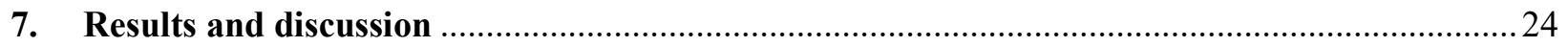

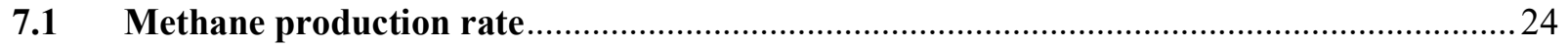

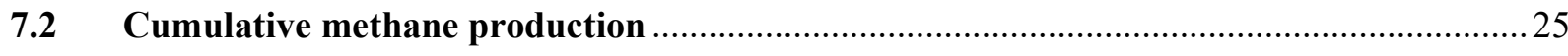

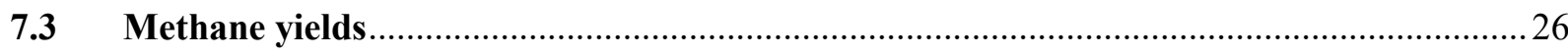

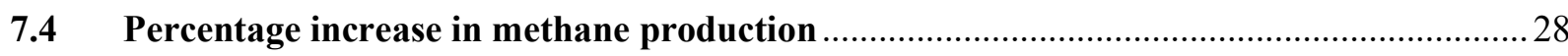

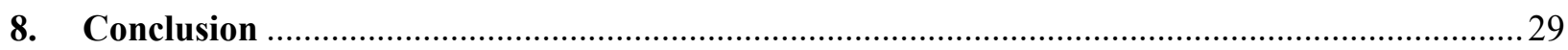

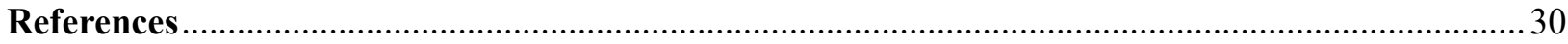

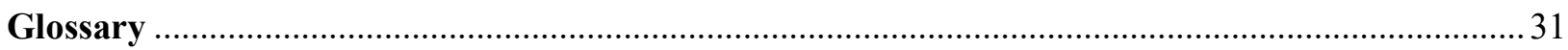




\section{List of Tables}

Table 1- Various feedstock from different sources (Steffen, Szolar, \& Braun, 1998).............................9

Table 2- Digester operating parameters (Wilkie, 2005)....................................................................... 14

Table 3- Characteristics of substrates and inoculum........................................................................... 16

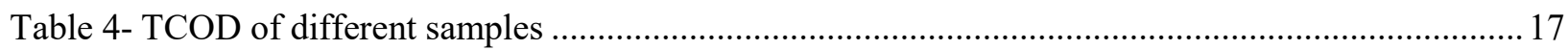

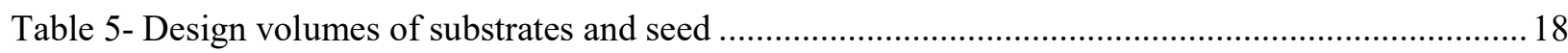

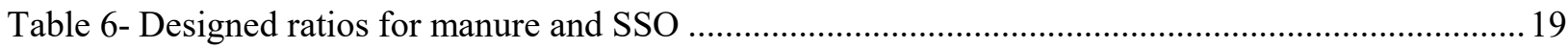

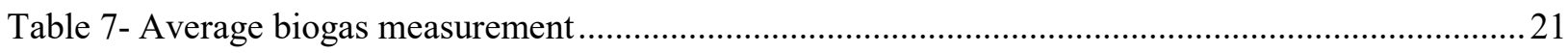

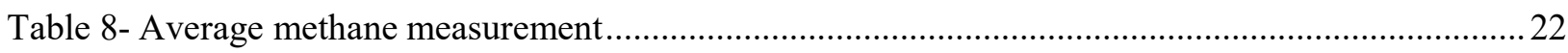

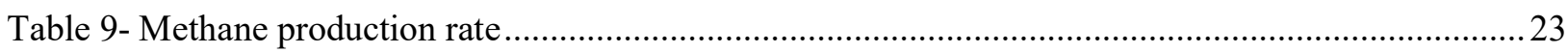

Table 10- \% increase in cumulative methane production ....................................................................28 


\section{$\underline{\text { List of Figures }}$}

Figure 1. Anaerobic digestion system components (https://www.tn.gov/environment/program-areas/sw-

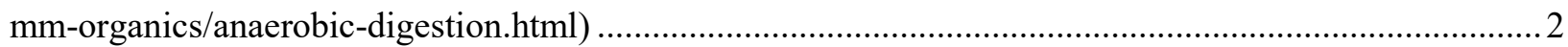

Figure 2. The pathway of AD process (http://www.appropedia.org/Arcata_Marsh_digester) ..................2

Figure 3. Advantages of AD system (https://biogts.com/products/biogas-plants/) ................................. 3

Figure 4. Anaerobic co-digestion system (Kennedy, 2015) ............................................................. 6

Figure 5. Sources of feedstocks for AD process (Graphic by Devarshi Sevak) .................................... 8

Figure 6. Methane yields of different substrates (Kennedy, 2015) .......................................................

Figure 7. Waste separation at source (https://divertns.ca/resources/bins-signage/bin-guidelines) ............ 10

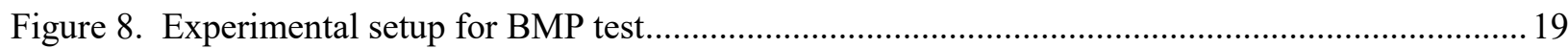

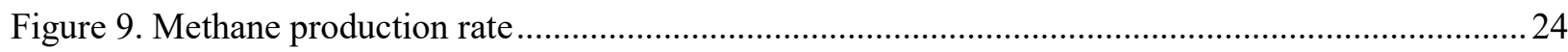

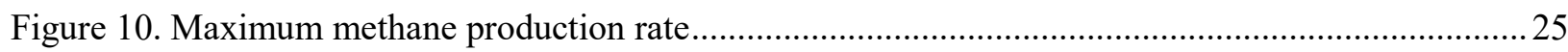

Figure 11. Cumulative methane production at different mixing ratios ...............................................25

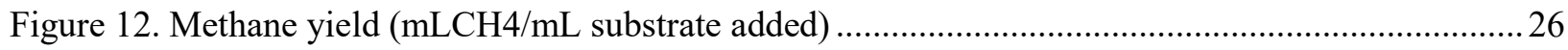

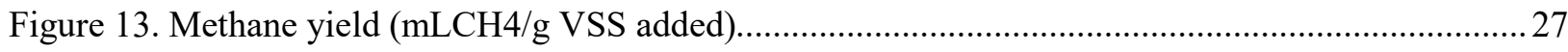

Figure 14. Methane yield (mLCH4/g TCOD added) .........................................................................2 27 


\section{Introduction}

Nowadays many countries facing the most crucial problems for the disposal of many types of wastes like Municipal Solid Waste (MSW), Sewage Sludge (SS), Dairy Manure (DM) and crop residues. There are different types of methods available for the proper disposal and recycling of these kind of wastes. Among all these methods, Anaerobic Digestion (AD) is one of the most successful method because of its minimum impact on the environment. It is one of the most suitable treatment techniques, because it converts such a waste in methane-rich biogas, which can be used as a valuable source of energy for heating and electricity generation.

Anaerobic digestion is a natural biological process. In this process anaerobic microbes break down the organic matters of the waste, release the gas and leave the non-biodegradable waste as a residue. This whole process operated in a closed reactor known as a 'Digester', in the absence of oxygen $\left(\mathrm{O}_{2}\right)$ with elevated temperature. Biogas, digestate and water are the three principal products of the AD process. Digestate is a nutrient rich by-product, which can be used as a fertilizer and soil improver.

Biogas is a mixture of $\mathrm{CH}_{4}, \mathrm{CO}_{2}$ and water, that can be used as a natural gas substitute and can be used to produce electricity and heat. Biogas typically contains $60 \%$ to $70 \%$ methane (by volume), $30 \%$ to $40 \%$ carbon dioxide and minor quantities of nitrogen, hydrogen, ammonia and hydrogen sulfide (usually less than $1 \%$ of the total gas volume). Among all these gases, methane is the most valuable gas, because it is a source of hydrocarbon fuel. Figure 1 shows the components of AD system. 


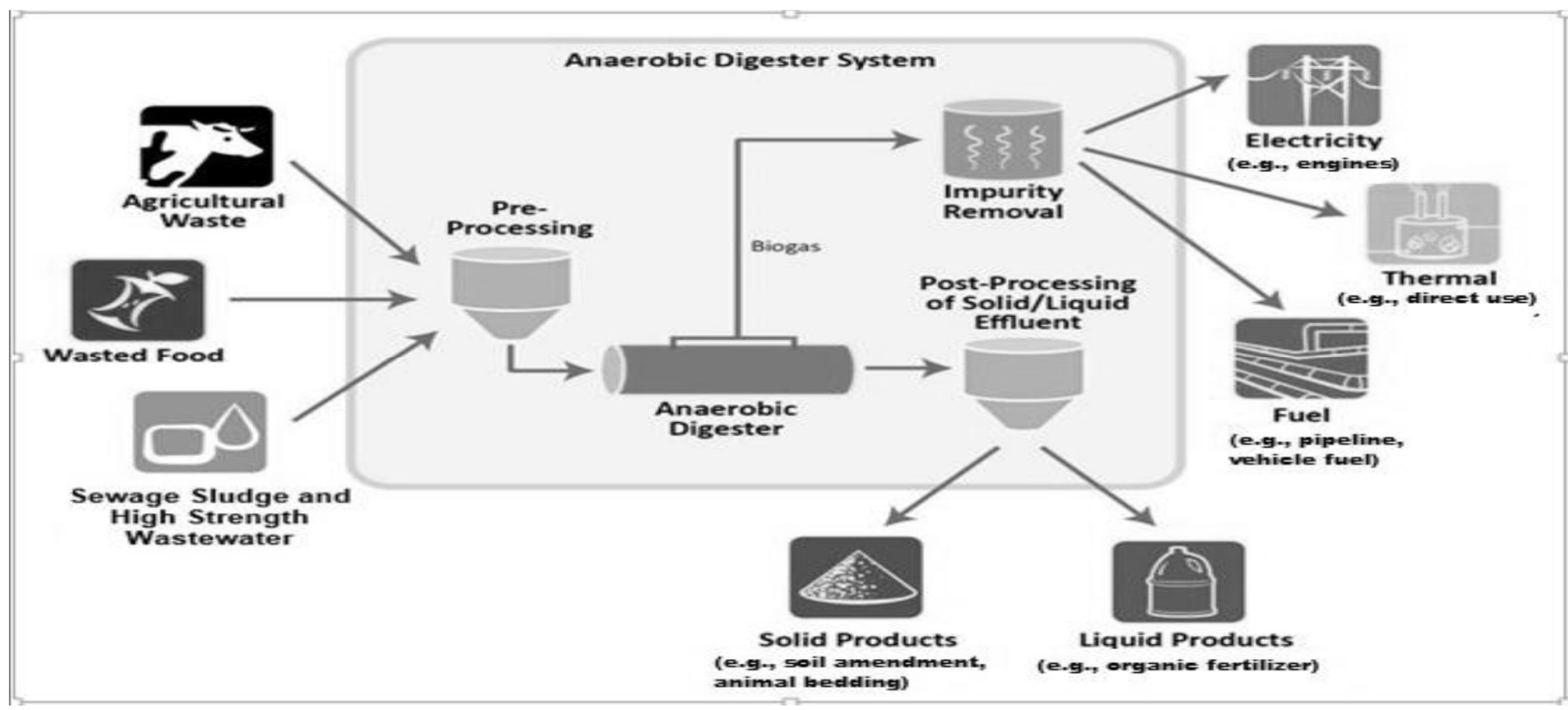

Figure 1. Anaerobic digestion system components (https://www.tn.gov/environment/program-areas/sw-mmorganics/anaerobic-digestion.html)

In $\mathrm{AD}$ process complex organic substrates are break down by anaerobic microorganisms and converted to $\mathrm{CO}_{2}, \mathrm{CH}_{4}$ and digested solid compost. This biodegradation process goes through four different phases named hydrolysis, fermentation (acidogenesis), acetogenesis and methanogenesis. Figure 2 shows the breakdown of complex organic matters through the four phases of the AD process.

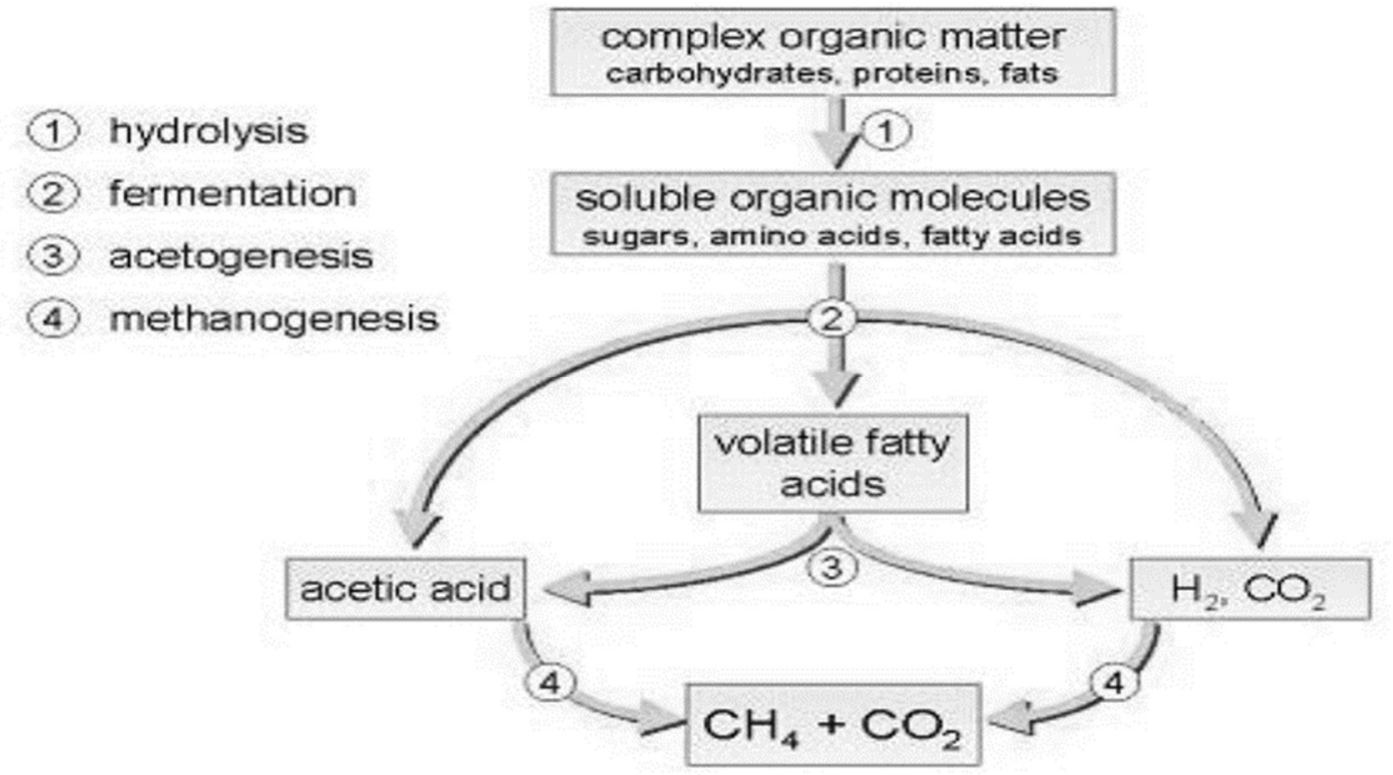

Figure 2. The pathway of AD process (http://www.appropedia.org/Arcata_Marsh_digester) 
There are many advantages of using $\mathrm{AD}$ process as a treatment method for the waste management. Some of the major advantages are listed below.

- Climate change mitigation (Methane emission reduction)

- Diversion of organics from landfills

- Economic benefits

- Less sludge production

- Manure management

- Renewable energy generation

- Soil improvement opportunities

- $\mathrm{AD}$ systems can minimize odors and vector attraction, reduce pathogens, produce gas, produce liquid and solid digestate, and reduce waste volumes.

- Biogas can be converted to energy via a Combined Heat \& Power Plant (CHP). Electricity generated from the CHP process can be used in adjacent industrial or commercial enterprises or can be fed into the national grid. Surplus heat generated can be used in industrial processes or for district heating systems.

Figure 3 shows the benefits of using AD system as a treatment method for the waste management.

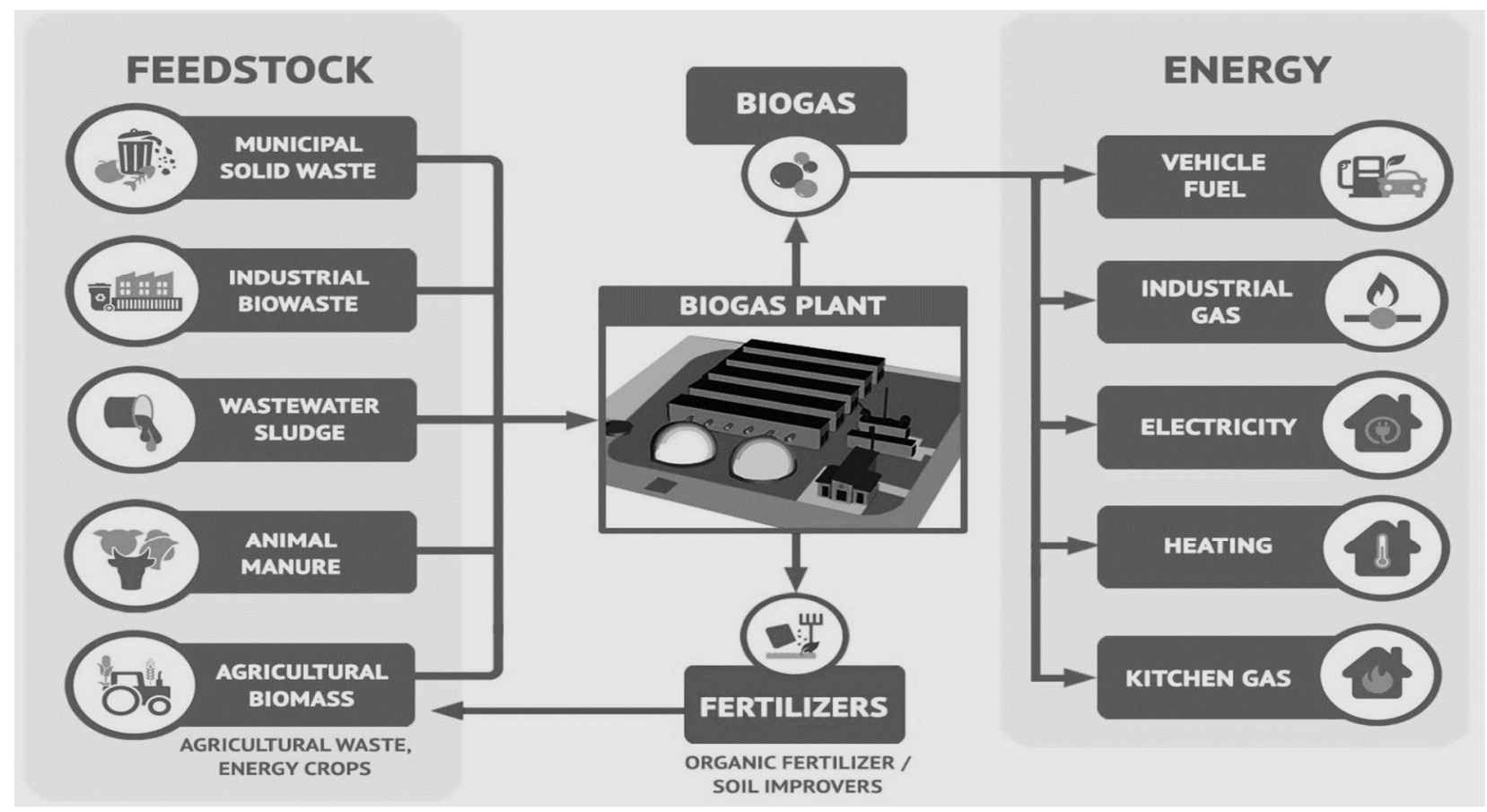

Figure 3. Advantages of AD system (https://biogts.com/products/biogas-plants/) 
Although AD systems offer several advantages, there are some drawbacks of using $\mathrm{AD}$ system that needs to be considered. Some of the major disadvantages are listed below.

- Does not remove ammonia-nitrogen.

- Does not reduce some nutrients such as $\mathrm{N}, \mathrm{K}$ and $\mathrm{P}$.

- High initial capital cost; high cleaning cost.

- High operator attention is required for safety concerns because methane is an explosive gas.

- $\mathrm{pH}$ must be controlled along with monitoring of volatile fatty acids.

- Time consuming process because methanogenesis stage is very slow. 


\section{Anaerobic co-digestion}

Anaerobic digestion produces renewable energy by converting the complex organic matters into biogas. However, this process takes place in completely monitored environment, because of some important parameters that affects the biogas production rate. Some important parameters need to be controlled during the process such as $\mathrm{C}: \mathrm{N}$ ratio, $\mathrm{pH}$ value, temperature etc. to achieve better methane production rate. As in $\mathrm{AD}$ process only one substrate decomposes at a time; due to some factors like $\mathrm{C}$ : $\mathrm{N}$ ratio, desired production rate of biogas cannot be achieved. For example, sewage sludge is a poor feed source for AD process because it has high nitrogen and low carbon content (M. Elsayed, 2015). To avoid such type of problem, if two or more different substrates in one digester simultaneously are used; higher amount of biogas production can be achieved.

Co-digestion is the simultaneous digestion of homogenous mixture of two or more than two substrates in the same digester (A.O. Adebayo, 2014). Co-digestion has some benefits over traditional mono-digestion. The main advantage of using co-digestion is the significant improvement is the biogas production. In co-digestion, by adding two different substrates we can achieve optimum $\mathrm{C}: \mathrm{N}$ ratio, which is very crucial parameter for the biogas generation. For example, an optimum $\mathrm{C}$ : $\mathrm{N}$ ratio can be obtained by adding a carbon rich waste to the sewage sludge (Richard Wickham, 2016). This project focuses on the co-digestion of Source Separated Organics (SSO) and Manure. Effects of the co-digestion of SSO and manure on methane production has been studied and analyzed in this project. 


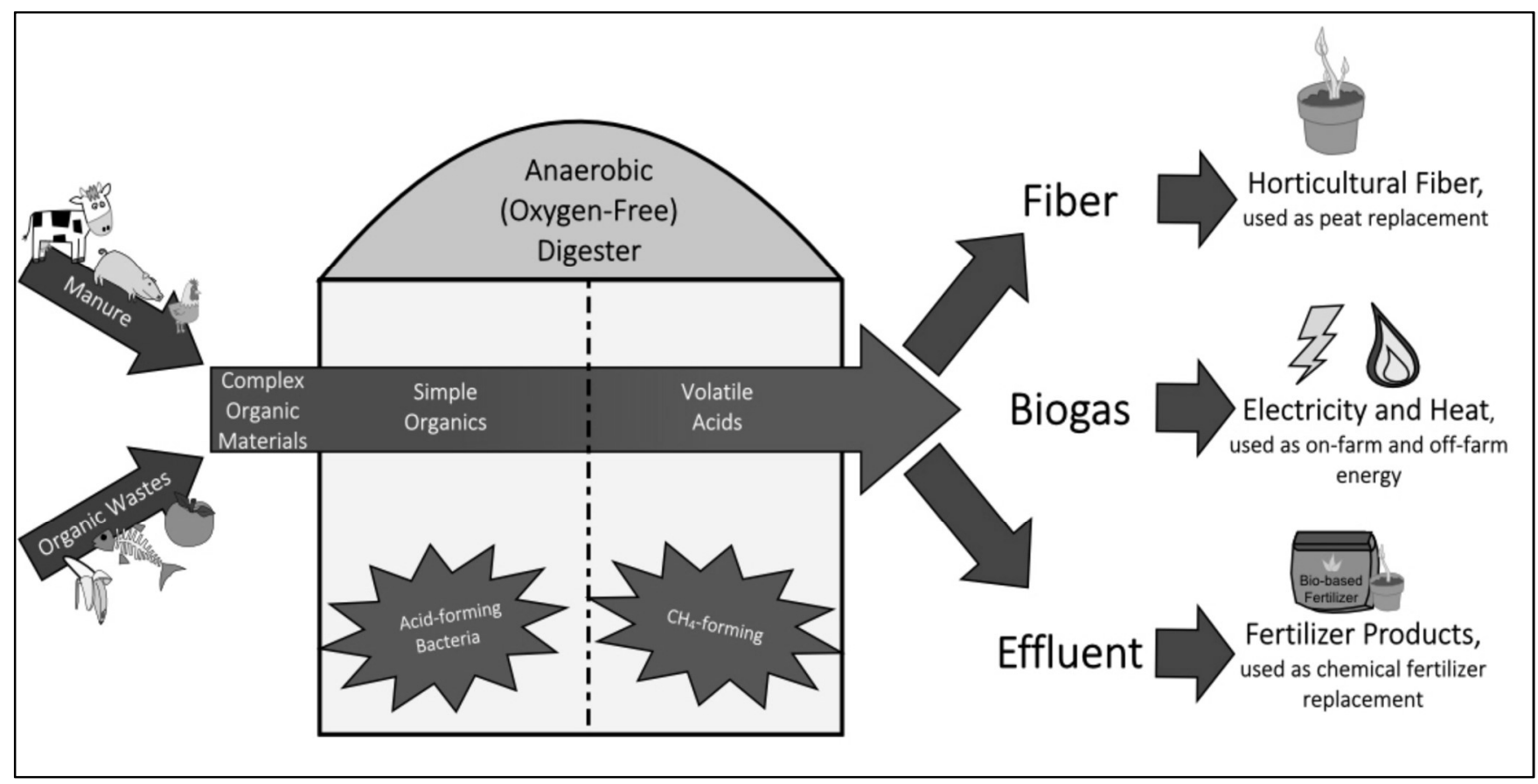

Figure 4. Anaerobic co-digestion system (Kennedy, 2015)

When adding two or more different substrates in the digester, some modification in the infrastructure of the digester is necessary based on the type of the substrates added. Studies have shown that biogas production is higher in co-digestion compared to mono-digestion; because in co-digestion balanced nutrients and high energy organic material is fed to the digester. The produced biogas can be used for electricity and heat generation. It can be also upgraded to Renewable Natural Gas (RNG) (Kennedy, 2015). The biogas production rate highly depends on the type and concentration of the substrates that are used in co-digestion process. It also depends on the flow rate of the substrates throughout the process. Some of the common advantages and disadvantages of co-digestion process is mentioned below (Kennedy, 2015).

\subsection{Advantages of co-digestion process}

- Diversion of organic matters from the landfills

- Improved overall process economics by producing higher biogas

- Reduction of the greenhouse gas (GHG) emissions

- Improved fertilizer value of the digestate due to less solids and higher degradation

- Enhanced C: $\mathrm{N}$ ratio and nutrients balance by substrates combinations 


\subsection{Disadvantages of co-digestion process}

- Inorganic materials (e.g. metals, plastics etc.) can negatively impact the digester performance

- Higher biogas production leads to higher biogas contaminants (e.g. hydrogen sulfide and carbon dioxide)

- Increased nutrients such as nitrogen, phosphorous and potassium from the substrate can affect the quality of the digestate

- Possibility of digester failure due to biological inhibition process occurred within the codigested substrates 


\section{Feedstocks}

Feedstock can be defined as any biodegradable substrates which can be converted to biogas by anaerobic microbes. It can be easily degradable or complex high-solid waste. Using specific technologies toxic compounds can also be degraded anaerobically. Adequate organic matters must be present in the feedstock, so that they can be finally converted to biogas which is comprised mainly of methane.

Feedstocks for the AD process is derived from one major source. Initially, AD was designed for the treatment of animal manure. But due to population growth and urbanization, amount of different kind of waste material is also increased. Therefore, since 1970s industrial and municipal solid wastes are also introduced to AD applications to fulfill the demand of the new waste management strategies and renewable energy forms (Steffen, Szolar, \& Braun, 1998). Figure 3 shows the eligible main sources of the feedstocks for AD process.

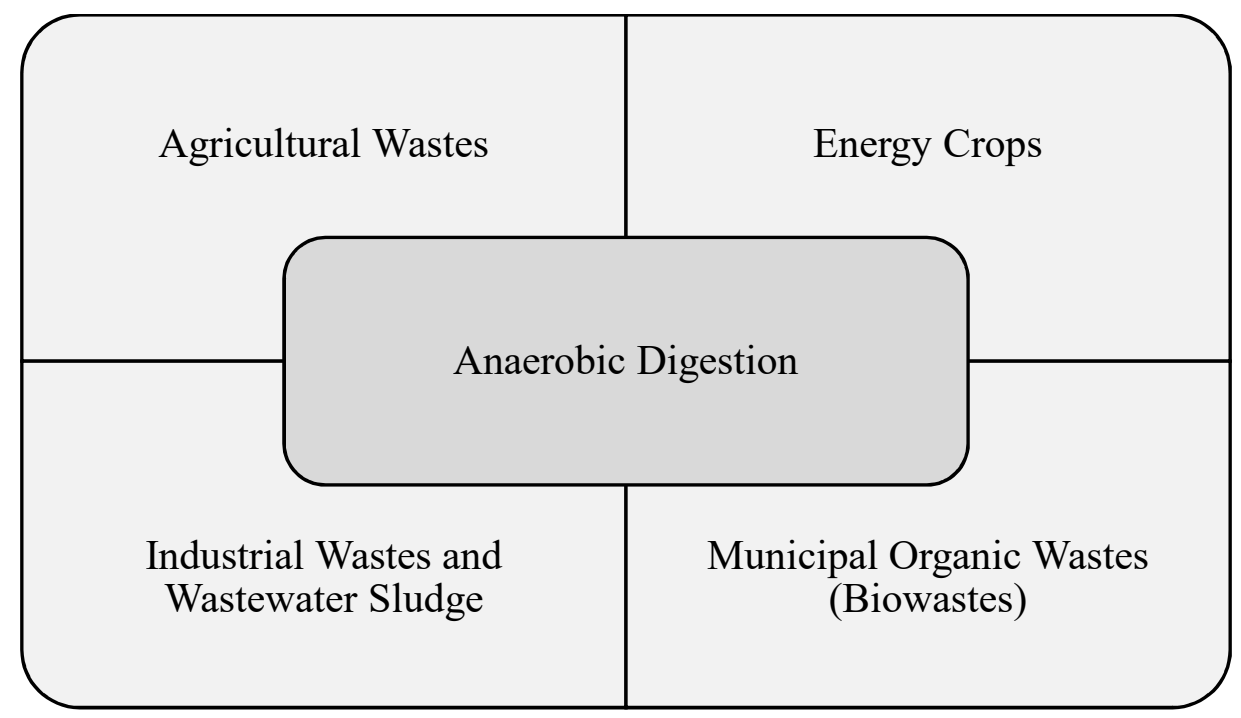

Figure 5. Sources of feedstocks for AD process (Graphic by Devarshi Sevak) 
There are many types of substrates that can be used as a feedstock in AD process. The following table shows the broad classification of the main sources of the feedstocks for the AD process.

Table 1- Various feedstock from different sources (Steffen, Szolar, \& Braun, 1998)

\begin{tabular}{|c|l|}
\hline Source of Feedstock & \multicolumn{1}{|c|}{ Various Feedstocks } \\
\hline Agricultural Waste & Manure (cattle, pig etc.) \\
\cline { 2 - 2 } & Algal biomass \\
\cline { 2 - 2 } & Harvest remains etc. \\
\hline Communities & Municipal Solid Waste (MSW) \\
\cline { 2 - 2 } & Sewage Sludge \\
\cline { 2 - 2 } & Yard Waste etc. \\
\hline Industry & Food/beverage processing waste \\
\cline { 2 - 2 } & Dairy waste \\
\cline { 2 - 2 } & Pulp and Paper etc. \\
\hline
\end{tabular}

As mentioned earlier, the biogas production rate mainly depends on the type of substrate used and the amount of organic matters in the substrate. The following figure shows the data derived from a study at Cornell University, demonstrates a massive change in methane production based on different substrate types (Kennedy, 2015).

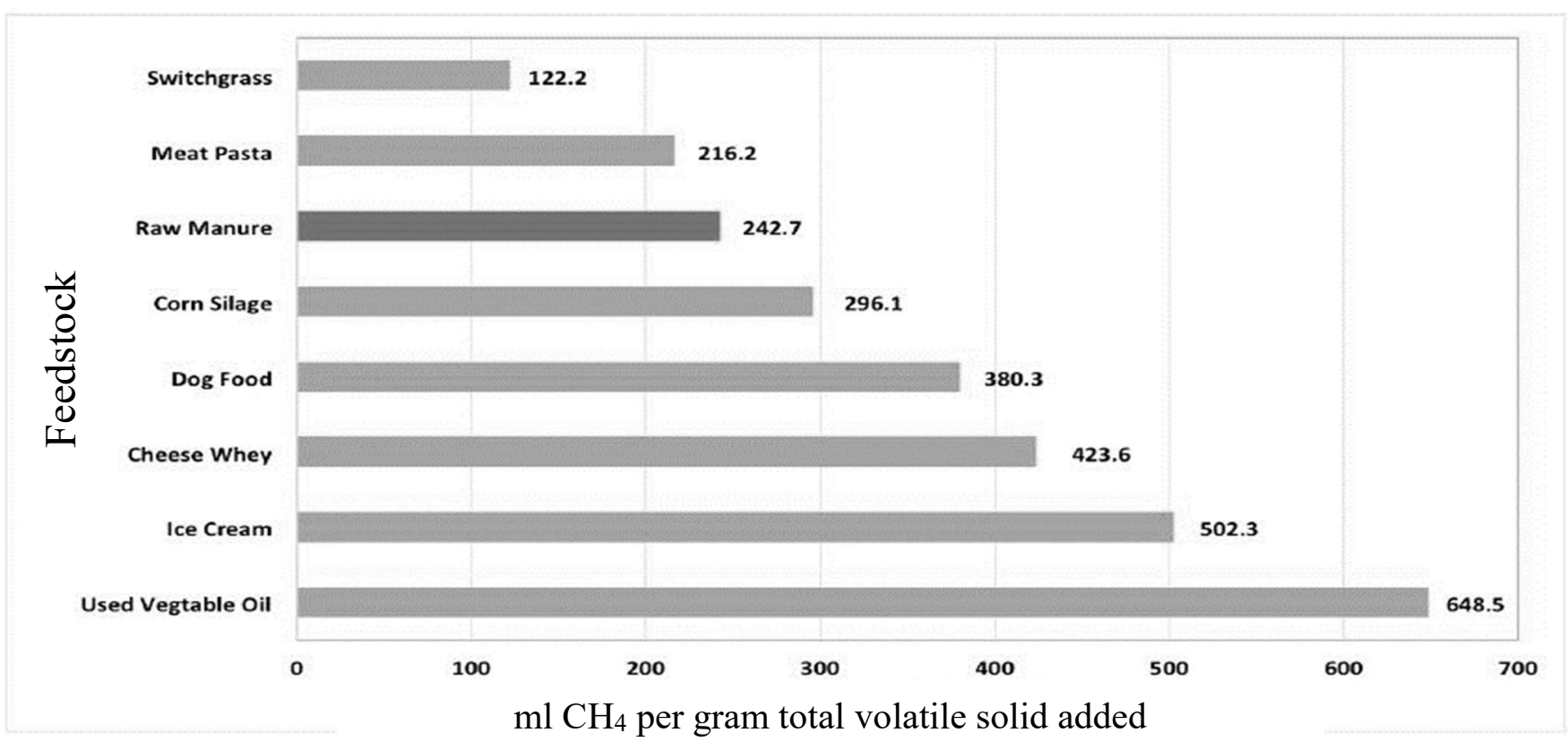

Figure 6. Methane yields of different substrates (Kennedy, 2015) 


\section{Co-digestion of SSO and manure}

In this project, co-digestion of $\mathrm{SSO}$ and manure in mesophilic condition at different mixture ratios of manure and SSO has been investigated. The effects of the co-digestion of these two substrates has been analyzed through the BMP assay to evaluate the mixture ratio on improving methane production.

\subsection{Source separated organics (SSO)}

Source Separated Organics (SSO) is the compostable organic waste which is segregated from other waste materials at the source. SSO refers to mostly food waste which is separated from the residential waste for separate collection and processing (Kelleher \& Robins, 2013). For the separate collection and processing of SSO, many municipalities (Ottawa, Toronto etc.) introduced the concept of using 'Green Bins' for the food waste. Following figure shows the separate collection bins of different wastes.
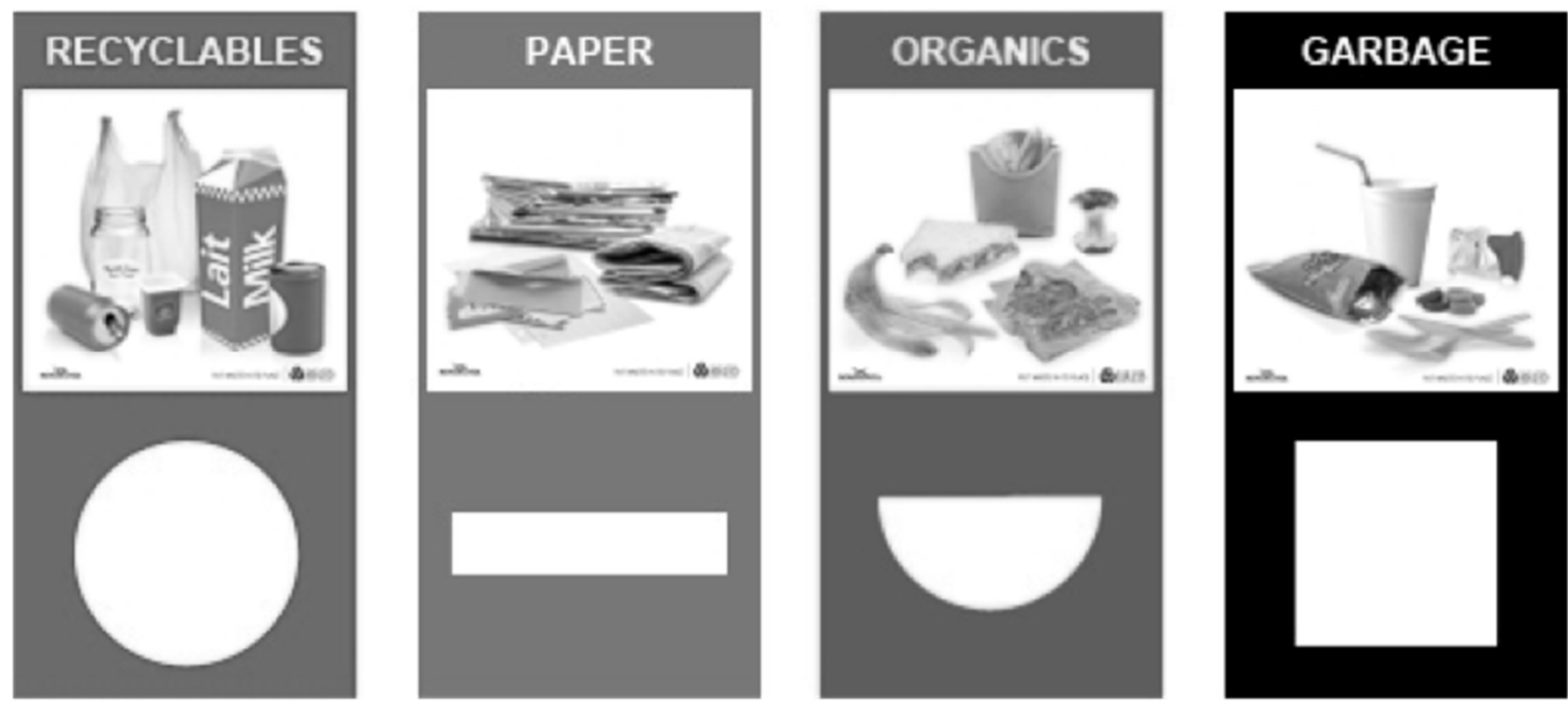

Figure 7. Waste separation at source (https://divertns.ca/resources/bins-signage/bin-guidelines)

Organic matters such as wood waste, food scraps, yard trimmings, paper and cardboard products, typically make up about 33\% (by weight) of the municipal solid waste stream. Generally, SSO programs depend on the composition of waste material, acceptance criteria of organics processing units and the collection method. So, the different types of organic matters include the following wastes. 
- Yard and Landscaping debris- Tree trimming, grass, leaves etc.

- Food Waste- vegetables, meat, seafood, bones, rice, eggshells, bakery items etc.

- Paper Fibers- napkins, paper towels, tea bags, coffee filters etc.

- Wood Waste- urban wood waste, rural forestry residuals etc.

\subsubsection{SSO from residential sources}

The most common wastes generated at residents include food waste, paper waste, yard waste etc. Separating food waste from other garbage has significant benefits at the landfill or disposal site, as organics break down in landfills and generate strong greenhouse gases and leachate which is acidic and precipitates metals from the landfilled material. So, the segregation of food waste from other wastes is very important. There are some benefits of AD of Residential SSO and are as follows:

- Green House Gases and other Air Emissions

Anaerobic digestion of residential SSO produced less air and water pollution than aerobic composting and landfilling of residential SSO. It has positive net energy balance; while other methods including landfilling with gas collection- consume energy over their lifetime.

- Air Quality Impacts

AD system produces lower gas emissions. It has a significant air quality benefit compared to composting. AD of Green Bin material (residential SSO) occurs in a tightly controlled environment, where all the produced gas is cleaned through a biofilter; so that odors do not occur.

\subsubsection{SSO from industrial, commercial and institutional sources}

Waste composition studies carried out for several communities by Kelleher Environmental have indicated that about $23 \%$ of waste generated by the non-residential industrial, commercial and institutional sector (IC\&I) is food waste generated by businesses and institutions in all communities across Canada. Restaurants, hotels, hospitals and different food processing facilities generate most of the food waste. Food wastes from these different sources can generate considerable amount of biogas through the AD process. 


\subsection{Manure}

Animal manure is a valuable source of nutrients and renewable energy. However, majority of the manure is collected in lagoons or left to decompose in the open which results in a significant environmental and ecological risk. The air contaminants emitted from manure include methane, nitrous oxide, ammonia, hydrogen sulfide, volatile organic compounds and particulate matter, which can cause serious environmental concerns and health problems.

All animal manures are valuable sources of crop nutrients and manure represents a substantial bioenergy recourse if processed by anaerobic digestion. Anaerobic digestion is a unique treatment solution for animal manure as it can deliver positive benefits related to multiple issues, including renewable energy, water pollution, and air emissions. Although, there are some important factors including $\mathrm{pH}$, temperature and $\mathrm{C}$ : $\mathrm{N}$ ratio which must be considered for enhance biogas recovery. Neutral $\mathrm{pH}$, mesophilic temperature of around $35^{\circ} \mathrm{C}$ and $\mathrm{C}: \mathrm{N}$ ratio of $25: 1$ is considered ideal for maximum gas production.

The fresh animal manure is stored in an accumulation tank before its processing to the homogenization tank which is equipped with a mixer to facilitate homogenization of the waste stream. The consistently mixed waste is passed through a macerator to obtain uniform particle size of 5-10 $\mathrm{mm}$ and pumped into suitable-capacity anaerobic digesters where stabilization of organic waste happens. 


\section{Anaerobic co-digestion technology-review}

The usage of different mixture of waste in anaerobic co-digestion for biomethane recovery has been studied and some of them are discussed in the following sections. Below is summary of some studies on anaerobic co-digestion.

\subsection{Anaerobic co-digestion of organic wastes (G. Esposito, 2012)}

The study carried out in the paper focused on three important aspects;

(1) the analysis of the organic substrates typically co-digested to exploit their complementary characteristics;

(2) the need of pre-treating the substrates before their digestion to change their physical and/or chemical characteristics;

(3) the usefulness of mathematical models simulating the anaerobic co-digestion process.

This study verified that combination of different organic wastes results in a better-balanced and assorted substrate in terms of nutrients. It demonstrated that pre-treatments make the organic solid wastes more accessible and degradable to microbes. A mathematical model was also developed, which can be useful externally to predict the performance of co-digestion process and as a result, it can be useful in selecting the best suitable substrates to mix and proper pretreatment methods to be applied. The pretreatment methods which were applied in this study included 'Physical pretreatment', 'Biological and physical-chemical pre-treatment' and 'Thermal pre-treatment'.

\subsection{Anaerobic digestion of dairy manure: design and process considerations (Wilkie, 2005)}

Ann W. discussed in the study about the benefits of using AD system for dairy farms. In this study four different types of digester designs are described as an existing design which includes Covered lagoon, Plug-flow, Complete mix and Fixed film. This study also provided the information about different parameters for each types of digester which is summarized in Table-2. 
Table 2- Digester operating parameters (Wilkie, 2005)

\begin{tabular}{|l|l|l|l|}
\hline Digester Type & Total solids & HRT (days) & Temperature \\
\hline Covered lagoon & $<2 \%$ & $35-60$ & Ambient \\
\hline Fixed film & $<2 \%$ & $2-4$ & Ambient/Mesophilic \\
\hline Complete-mix & $3-10 \%$ & $20-25$ & Mesophilic \\
\hline Plug-flow & $10-14 \%$ & $20-30$ & Mesophilic \\
\hline
\end{tabular}

Note; Ambient temp. $=15-20^{\circ} \mathrm{C}$ and Mesophilic temp. $=30-40^{\circ} \mathrm{C}$

Impact of manure characteristics were also evaluated in this study. The most important parameters for characterizing manure were reported to be total solids (TS) and volatile solids (VS) contents. The process flow for flushed manure and scraped manure digestion was also investigated in this study. The author concluded the following two main points from the study:

- $\mathrm{AD}$ is a unique treatment solution for animal agricultural waste. It has positive advantages in terms of renewable energy, air and water pollution.

- $\mathrm{AD}$ offers an environmentally sustainable solution for livestock manure management.

\subsection{Biomethane potential evaluation of co-digestion of sewage sludge and organic wastes (Richard Wickham B. G., 2016)}

In the study conducted by Richard Wickham B. G., 2016, it was confirmed that the suitability of the organic rich waste depends on its ability to produce biogas as well as its influence on the overall anaerobic digestion process. They used seven different organic wastes and dehydrated algae for the biomethane potential evaluation. After performing all the experiments, based on the results they obtained, they concluded that all co-substrates increased the bio-methane yield by three to six times compared with conventional anaerobic digestion of sewage sludge.

Maximum co-digestion ratios were identifiable for most solid co-substrates including algae (6\% $\mathrm{wt} / \mathrm{wt})$, undiluted food waste $(5 \% \mathrm{wt} / \mathrm{wt})$, bakery waste $(5 \% \mathrm{wt} / \mathrm{wt})$, and diluted commercial food waste $(10 \% \mathrm{wt} / \mathrm{wt})$. The maximum co-digestions ratio of beverage rejects, and sewage sludge was $10 \%(\mathrm{wt} / \mathrm{wt})$. The increase in COD removal when co-digesting wastewater sludge and liquid waste was from 2 to $41 \%$. 


\subsection{Anaerobic co-digestion of cattle slurry with maize stalk at mesophilic temperature (A.O. Adebayo, 2014)}

A study carried out by A.O. Adebayo, 2014 on anaerobic co-digestion of dairy manure (DM) and maize stalk. The experiment performed by authors at mesophilic temperature $\left(37^{\circ} \mathrm{C}\right)$ by mixing cow slurry and maize stalk in the batch digester with different mixing ratios. The two substrates were co-digested at different ratios of 3:1,1:1 and 1:3 using the percentage volatile solid of each substrate. The experiment was performed in a laboratory scale in batch mode. The biogas yields for all three samples were analyzed. The measured biogas yields for the samples with the ratios $3: 1,1: 1$ and $3: 1$ at mesophilic temperature were $0.426,0.385$ and $0.391 \mathrm{~m}^{3} / \mathrm{kg}_{\mathrm{DM}}$ respectively, while the methane yields were $0.297,0.270$ and $0.262 \mathrm{~m}^{3} \mathrm{CH}_{4} / \mathrm{kg}_{\mathrm{DM}}$ respectively. The maximum biogas yields of $0.426 \mathrm{~m}^{3} / \mathrm{kg}_{\mathrm{DM}}$ was obtained for the mixing ratio of $3: 1$ (dairy manure to maize stalks). Methane concentration for the ratios of 3:1, 1:1 and 1:3 were 69.66, 70.24 and $66.98 \%$ respectively. So, the study verified that mixing ratio of $3: 1$ is the optimal for the co-digestion of cattle slurry (dairy manure) and maize stalks at $37^{\circ} \mathrm{C}$ i.e. mesophilic temperature. 


\section{Material and methodology}

Co-digestion of SSO and manure with different mixing ratios has been studied through a BMP assay. The experiment was performed with batch reactors in the laboratory at mesophilic temperature $\left(37^{\circ} \mathrm{C}\right)$ as it is the most favorable temperature for methanogenic microbes according to the literatures. The batch reactors operated in working volume of $0.2 \mathrm{~L}(200 \mathrm{~mL})$ for 52 days. During the whole process, speed of 150 RPM was applied for proper mixing. The main objective of this project was to find out the optimum mixing ratio of SSO and manure to achieve higher methane production.

\subsection{Feedstocks and inoculum}

Cow manure was obtained from a manure pit of a dairy farm located in New market, Ontario. SSO sample was collected from Disco Road Organics Processing Facility, Toronto, Ontario. The inoculum (seed) was obtained from Ash Bridges Bay Wastewater Treatment Plant, Toronto, Ontario. Samples were transported and preserved according to Standard Methods for the Examination of Water and Wastewater.

\subsection{Characteristics of substrates and inoculum}

For the design of batch reactor, characterization of the substrates and inoculum is necessary. TSS and VSS concentration was measured in triplicates corresponding to the Standard Methods for the Examination of Water and Wastewater (1999). To measure the TCOD, high range (20-1500 mg/L) COD reagent vials and HACH DR 3900 spectrophotometer were used. The TCOD analysis was conducted according to the procedure specified by HACH. Table-3 shows some of the characteristics of the substrates and the inoculum in summary.

Table 3-Characteristics of substrates and inoculum

\begin{tabular}{|c|c|c|c|c|c|}
\hline Sample & TCOD (mg/L) & TS (mg/L) & VS (mg/L) & TSS (mg/L) & VSS (mg/L) \\
\hline Inoculum & 17167 & 16590 & 10180 & 15400 & 9500 \\
\hline Manure & 106733 & 73727 & 38647 & 86520 & 47698 \\
\hline SSO & 206267 & 68187 & 47493 & 56899 & 39478 \\
\hline
\end{tabular}




\subsection{Sample preparation}

Manure slurry was prepared by addition and homogenization of cow manure with deionized distilled water using a blender. SSO samples also were homogenized using a blender and mixed with the manure slurry and the inoculum at different mixing ratios. The reactors were fed with the mixtures immediately after preparation.

\subsection{Design of the batch reactors}

Batch tests were carried out at five different mixing ratios in triplicates. Manure and SSO alone as control reactors, and inoculum (seed) without any feedstock were used as blank reactors in triplicates as well. Co-digestion of manure with $\mathrm{SSO}$ was conducted at the mixing ratios of 9:1, 7:3, 5:5, 3:7, and 1:9 on a volumetric basis. The COD equivalent for these samples are shown in the Table 4.

Table 4- TCOD of different samples

\begin{tabular}{|c|c|c|}
\hline Samples & TCOD (COD eq.) $(\mathbf{m g} / \mathbf{L})$ & TCOD $($ COD eq.) $(\mathbf{g} / \mathbf{L})$ \\
\hline Manure only & 106733 & 107 \\
\hline SSO only & 206267 & 206 \\
\hline M: $=9: 1$ & 116686 & 117 \\
\hline M: $S=7: 3$ & 136593 & 137 \\
\hline M: $S=5: 5$ & 156500 & 157 \\
\hline M: $S=3: 7$ & 176406 & 176 \\
\hline M: $S=1: 9$ & 196313 & 196 \\
\hline
\end{tabular}

Total sample of $200 \mathrm{ml}$ was filled in the reactors. The value of Food to micro-organisms ratio (F/M) was 2 . The volume of the substrates and seed were calculated using the following equation. Table5 shows the calculated volume of substrates and seed. 


$$
\begin{array}{lc}
\frac{F}{M}=\frac{\text { gTCODsubstrate }}{\text { gVSSseed }}=\frac{\text { Vsub. } * \text { TCODsub. }}{\text { Vseed } * \text { VSSseed }} & \text { Eq. } 1 \\
\text { Total Volume }=\text { Vsubstrate }+ \text { Vseed } & \text { Eq. } 2 \\
\text { Vseed }=\text { Total Volume }- \text { Vsubstrate } & \text { Eq. } 3
\end{array}
$$

Table 5-Design volumes of substrates and seed

\begin{tabular}{|c|c|c|c|c|}
\hline Samples & $\begin{array}{c}\text { Substrate } \\
\text { Volume }\end{array}$ & $\begin{array}{c}\text { Manure } \\
\text { Volume }\end{array}$ & SSO Volume & Seed Volume \\
\hline Manure only & 30 & 30 & 0 & 170 \\
\hline SSO only & 17 & 0 & 17 & 183 \\
\hline M: S $=9: 1$ & 28 & 25 & 3 & 172 \\
\hline M: S $=7: 3$ & 24 & 17 & 7 & 176 \\
\hline M: $S=5: 5$ & 22 & 11 & 11 & 178 \\
\hline M: $:=3: 7$ & 19 & 6 & 13 & 181 \\
\hline M: S $=1: 9$ & 18 & 2 & 16 & 182 \\
\hline
\end{tabular}

Note: unit of the volume $=\mathrm{ml}$

\subsection{Biochemical methane potential (BMP) assay}

An experimental study, using anaerobic batch reactors were carried out at mixing speed of 150 RPM, in triplicates under mesophilic temperature, which is most favorable condition for methanogenic microbes. To achieve the best mixing ratio of SSO and manure for effective biogas production five different mixing ratios were tested in triplicates. Manure and SSO were also tested alone as a control reactor in triplicates. The experimental setup is shown in Figure 8. The following table shows the details about the bioreactors. 
Table 6-Designed ratios for manure and SSO

\begin{tabular}{|c|c|}
\hline Bottle No. & M: S ratios \\
\hline $1,2,3$ & Manure only \\
\hline $4,5,6$ & SSO only \\
\hline $7,8,9$ & M: $\mathrm{S}=9: 1$ \\
\hline $10,11,12$ & M: $\mathrm{S}=7: 3$ \\
\hline $13,14,15$ & M: $\mathrm{S}=5: 5$ \\
\hline $16,17,18$ & M: $\mathrm{S}=3: 7$ \\
\hline $19,20,21$ & M: $\mathrm{S}=1: 9$ \\
\hline
\end{tabular}

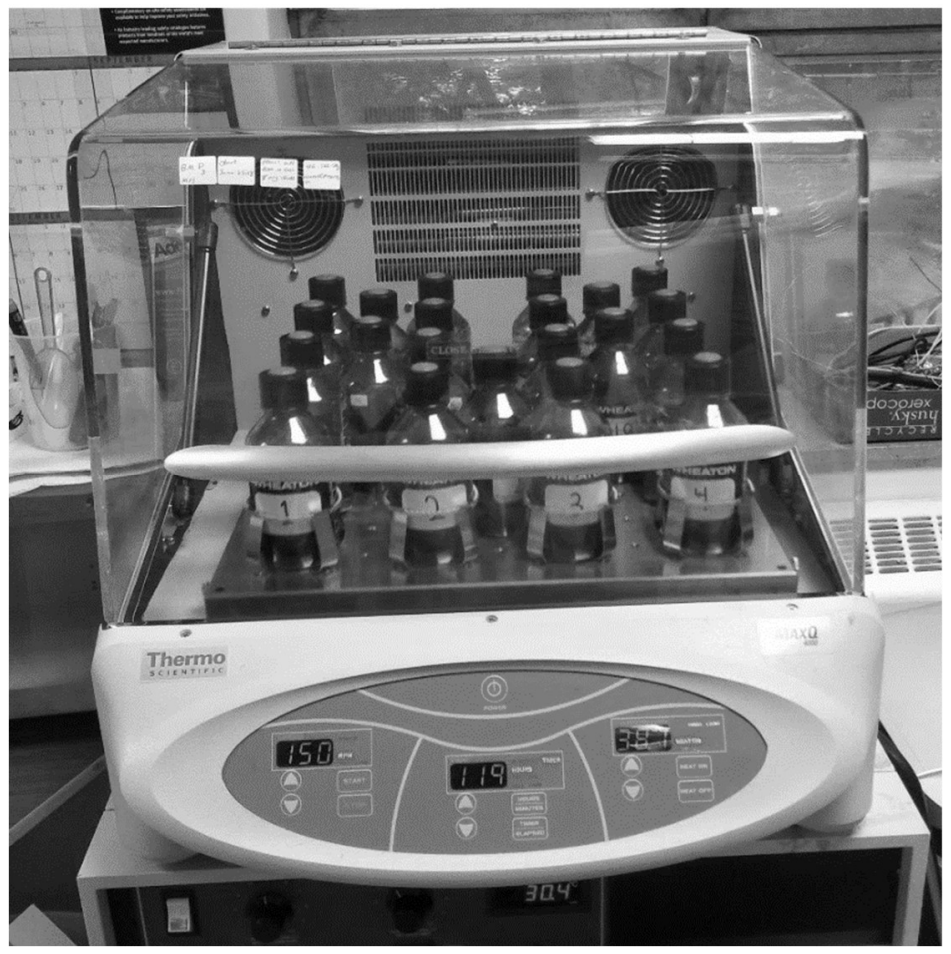

Figure 8. Experimental setup for BMP test 


\subsection{Data collection and analysis}

The experiment has been carried out on a laboratory scale. Gas measurement was carried out on daily basis. The gas was measured by using $100 \mathrm{ml}$ Gastight Luer-Lock syringe at the initial stage of the experiment, because of higher gas production. But, in the final stage of the experiment (i.e. last 10-15 days); the gas production was lower so, gas was measured using $50 \mathrm{ml}$ Gastight LuerLock syringe for the most accurate readings. Then, the measured biogas data was analyzed to find the most suitable mixing ratio of manure and $\mathrm{SSO}$; for maximum methane production rate.

For the data analysis, amount of daily methane production is required. Theoretical approach was used to find methane production on the daily basis. For the first five days, the amount of methane produced is $10,20,30,40$ and $50 \%$ of the biogas respectively. From the $6^{\text {th }}$ day onwards, the amount of methane is $60 \%$ of the biogas. Then, this data of methane production was used for the analysis of cumulative methane production, maximum methane production rate and different kind of methane yields. The data for the biogas production is shown in table 7 . The table shows the average biogas measurement on daily basis with respect to different mixing ratios. 
Table 7- Average biogas measurement at different mixture ratio $(\mathrm{mL})$

\begin{tabular}{|c|c|c|c|c|c|c|c|}
\hline Day & $\begin{array}{l}\text { Manure } \\
\text { only }\end{array}$ & SSO only & $\mathrm{M}: \mathrm{S}=9: 1$ & $\mathrm{M}: \mathrm{S}=7: 3$ & $\mathrm{M}: \mathrm{S}=5: 5$ & $\mathrm{M}: \mathrm{S}=3: 7$ & $\mathrm{M}: \mathrm{S}=1: 9$ \\
\hline 1 & 126 & 97 & 124 & 130 & 110 & 117 & 99 \\
\hline 2 & 133 & 120 & 90 & 115 & 67 & 136 & 124 \\
\hline 3 & 119 & 138 & 76 & 93 & 62 & 135 & 142 \\
\hline 4 & 72 & 91 & 62 & 62 & 61 & 80 & 90 \\
\hline 5 & 68 & 83 & 56 & 58 & 51 & 73 & 82 \\
\hline 6 & 72 & 75 & 72 & 70 & 69 & 76 & 77 \\
\hline 7 & 57 & 57 & 56 & 55 & 55 & 58 & 61 \\
\hline 8 & 37 & 44 & 39 & 37 & 38 & 38 & 44 \\
\hline 9 & 36 & 47 & 37 & 36 & 39 & 35 & 43 \\
\hline 11 & 42 & 47 & 47 & 42 & 52 & 39 & 45 \\
\hline 12 & 24 & 22 & 31 & 26 & 37 & 22 & 22 \\
\hline 14 & 31 & 20 & 39 & 31 & 47 & 24 & 22 \\
\hline 15 & 16 & 11 & 25 & 18 & 28 & 14 & 12 \\
\hline 16 & 11 & 8 & 19 & 14 & 21 & 9 & 8 \\
\hline 17 & 10 & 7 & 17 & 12 & 20 & 8 & 7 \\
\hline 18 & 11 & 7 & 17 & 13 & 19 & 9 & 7 \\
\hline 20 & 16 & 11 & 25 & 20 & 29 & 14 & 12 \\
\hline 21 & 11 & 8 & 19 & 15 & 20 & 9 & 8 \\
\hline 22 & 8 & 5 & 14 & 10 & 16 & 7 & 6 \\
\hline 23 & 7 & 6 & 11 & 9 & 12 & 6 & 5 \\
\hline 24 & 7 & 4 & 11 & 9 & 12 & 6 & 5 \\
\hline 25 & 8 & 6 & 11 & 9 & 13 & 8 & 6 \\
\hline 26 & 8 & 4 & 11 & 9 & 12 & 6 & 5 \\
\hline 28 & 13 & 7 & 16 & 12 & 16 & 10 & 8 \\
\hline 29 & 7 & 5 & 11 & 9 & 12 & 6 & 6 \\
\hline 30 & 7 & 4 & 10 & 8 & 10 & 6 & 5 \\
\hline 31 & 3 & 3 & 7 & 5 & 9 & 3 & 2 \\
\hline 32 & 6 & 4 & 8 & 7 & 8 & 6 & 3 \\
\hline 35 & 11 & 7 & 15 & 13 & 17 & 10 & 8 \\
\hline 37 & 13 & 9 & 10 & 11 & 7 & 7 & 15 \\
\hline 40 & 11 & 7 & 15 & 12 & 16 & 10 & 8 \\
\hline 43 & 12 & 8 & 16 & 13 & 18 & 11 & 8 \\
\hline 46 & 10 & 5 & 13 & 12 & 14 & 9 & 8 \\
\hline 49 & 10 & 4 & 12 & 10 & 13 & 9 & 7 \\
\hline 52 & 9 & 6 & 12 & 10 & 12 & 8 & 7 \\
\hline
\end{tabular}


Using theoretical approach methane measurement was calculated. So, the methane measurement on the daily basis is presented in table 8 .

Table 8-Average methane measurement at different mixture ratio $(\mathrm{mL})$

\begin{tabular}{|c|c|c|c|c|c|c|c|}
\hline Day & $\begin{array}{l}\text { Manure } \\
\text { only }\end{array}$ & SSO only & $\mathrm{M}: \mathrm{S}=9: 1$ & $\mathrm{M}: \mathrm{S}=7: 3$ & $\mathrm{M}: \mathrm{S}=5: 5$ & $\mathrm{M}: \mathrm{S}=3: 7$ & $\mathrm{M}: \mathrm{S}=1: 9$ \\
\hline 1 & 13 & 10 & 12 & 13 & 11 & 12 & 10 \\
\hline 2 & 27 & 24 & 18 & 23 & 13 & 27 & 25 \\
\hline 3 & 36 & 41 & 23 & 28 & 19 & 41 & 43 \\
\hline 4 & 29 & 36 & 25 & 25 & 24 & 32 & 36 \\
\hline 5 & 34 & 42 & 28 & 29 & 26 & 37 & 41 \\
\hline 6 & 43 & 45 & 43 & 42 & 41 & 46 & 46 \\
\hline 7 & 34 & 34 & 34 & 33 & 33 & 35 & 37 \\
\hline 8 & 22 & 26 & 23 & 22 & 23 & 23 & 27 \\
\hline 9 & 22 & 28 & 22 & 22 & 23 & 21 & 26 \\
\hline 11 & 25 & 28 & 28 & 25 & 31 & 23 & 27 \\
\hline 12 & 15 & 13 & 19 & 15 & 22 & 13 & 13 \\
\hline 14 & 19 & 12 & 23 & 19 & 28 & 14 & 13 \\
\hline 15 & 9 & 7 & 15 & 11 & 17 & 8 & 7 \\
\hline 16 & 7 & 5 & 11 & 8 & 13 & 6 & 5 \\
\hline 17 & 6 & 4 & 10 & 7 & 12 & 5 & 4 \\
\hline 18 & 7 & 4 & 10 & 8 & 11 & 6 & 4 \\
\hline 20 & 10 & 7 & 15 & 12 & 17 & 8 & 7 \\
\hline 21 & 7 & 5 & 11 & 9 & 12 & 6 & 5 \\
\hline 22 & 5 & 3 & 8 & 6 & 9 & 4 & 4 \\
\hline 23 & 4 & 4 & 6 & 5 & 7 & 4 & 3 \\
\hline 24 & 4 & 3 & 7 & 6 & 7 & 4 & 3 \\
\hline 25 & 5 & 4 & 7 & 5 & 8 & 5 & 4 \\
\hline 26 & 5 & 3 & 7 & 5 & 7 & 4 & 3 \\
\hline 28 & 8 & 4 & 9 & 7 & 10 & 6 & 5 \\
\hline 29 & 4 & 3 & 6 & 5 & 7 & 4 & 3 \\
\hline 30 & 4 & 3 & 6 & 5 & 6 & 4 & 3 \\
\hline 31 & 2 & 2 & 4 & 3 & 5 & 2 & 1 \\
\hline 32 & 4 & 2 & 5 & 4 & 5 & 3 & 2 \\
\hline 35 & 7 & 4 & 9 & 8 & 10 & 6 & 5 \\
\hline 37 & 8 & 5 & 6 & 7 & 4 & 4 & 9 \\
\hline 40 & 7 & 4 & 9 & 7 & 10 & 6 & 5 \\
\hline 43 & 7 & 5 & 9 & 8 & 11 & 6 & 5 \\
\hline 46 & 6 & 3 & 8 & 7 & 8 & 5 & 5 \\
\hline 49 & 6 & 2 & 7 & 6 & 8 & 5 & 4 \\
\hline 52 & 5 & 3 & 7 & 6 & 7 & 5 & 4 \\
\hline
\end{tabular}


Table 9 shows the methane production rate.

Table 9- Methane production rate at different mixture ratio ( $\mathrm{mL} /$ day)

\begin{tabular}{|c|c|c|c|c|c|c|c|c|}
\hline Day & $\Delta \mathrm{t}$ & $\begin{array}{l}\text { Manure } \\
\text { only }\end{array}$ & SSO only & $\mathrm{M}: \mathrm{S}=9: 1$ & $\mathrm{M}: \mathrm{S}=7: 3$ & $\mathrm{M}: \mathrm{S}=5: 5$ & $\mathrm{M}: \mathrm{S}=3: 7$ & $\mathrm{M}: \mathrm{S}=1: 9$ \\
\hline 1 & 1 & 13 & 10 & 12 & 13 & 11 & 12 & 10 \\
\hline 2 & 1 & 27 & 24 & 18 & 23 & 13 & 27 & 25 \\
\hline 3 & 1 & 36 & 41 & 23 & 28 & 19 & 41 & 43 \\
\hline 4 & 1 & 29 & 36 & 25 & 25 & 24 & 32 & 36 \\
\hline 5 & 1 & 34 & 42 & 28 & 29 & 26 & 37 & 41 \\
\hline 6 & 1 & 43 & 45 & 43 & 42 & 41 & 46 & 46 \\
\hline 7 & 1 & 34 & 34 & 34 & 33 & 33 & 35 & 37 \\
\hline 8 & 1 & 22 & 26 & 23 & 22 & 23 & 23 & 27 \\
\hline 9 & 1 & 22 & 28 & 22 & 22 & 23 & 21 & 26 \\
\hline 11 & 2 & 13 & 14 & 14 & 13 & 16 & 12 & 14 \\
\hline 12 & 1 & 15 & 13 & 19 & 15 & 22 & 13 & 13 \\
\hline 14 & 2 & 9 & 6 & 12 & 9 & 14 & 7 & 7 \\
\hline 15 & 1 & 9 & 7 & 15 & 11 & 17 & 8 & 7 \\
\hline 16 & 1 & 7 & 5 & 11 & 8 & 13 & 6 & 5 \\
\hline 17 & 1 & 6 & 4 & 10 & 7 & 12 & 5 & 4 \\
\hline 18 & 1 & 7 & 4 & 10 & 8 & 11 & 6 & 4 \\
\hline 20 & 2 & 5 & 3 & 8 & 6 & 9 & 4 & 4 \\
\hline 21 & 1 & 7 & 5 & 11 & 9 & 12 & 6 & 5 \\
\hline 22 & 1 & 5 & 3 & 8 & 6 & 9 & 4 & 4 \\
\hline 23 & 1 & 4 & 4 & 6 & 5 & 7 & 4 & 3 \\
\hline 24 & 1 & 4 & 3 & 7 & 6 & 7 & 4 & 3 \\
\hline 25 & 1 & 5 & 4 & 7 & 5 & 8 & 5 & 4 \\
\hline 26 & 1 & 5 & 3 & 7 & 5 & 7 & 4 & 3 \\
\hline 28 & 2 & 4 & 2 & 5 & 4 & 5 & 3 & 2 \\
\hline 29 & 1 & 4 & 3 & 6 & 5 & 7 & 4 & 3 \\
\hline 30 & 1 & 4 & 3 & 6 & 5 & 6 & 4 & 3 \\
\hline 31 & 1 & 2 & 2 & 4 & 3 & 5 & 2 & 1 \\
\hline 32 & 1 & 4 & 2 & 5 & 4 & 5 & 3 & 2 \\
\hline 35 & 3 & 2 & 1 & 3 & 3 & 3 & 2 & 2 \\
\hline 37 & 2 & 4 & 3 & 3 & 3 & 2 & 2 & 5 \\
\hline 40 & 3 & 2 & 1 & 3 & 2 & 3 & 2 & 2 \\
\hline 43 & 3 & 2 & 2 & 3 & 3 & 4 & 2 & 2 \\
\hline 46 & 3 & 2 & 1 & 3 & 2 & 3 & 2 & 2 \\
\hline 49 & 3 & 2 & 1 & 2 & 2 & 3 & 2 & 1 \\
\hline 52 & 3 & 2 & 1 & 2 & 2 & 2 & 2 & 1 \\
\hline
\end{tabular}




\section{Results and discussion}

The measured data was analyzed to find methane production rate, cumulative methane production and methane yields. The results of the experiment are discussed in the following sections.

\subsection{Methane production rate}

The methane production rate for manure, SSO and different mixing ratios are shown in figure 9. All the samples have similar behavior for the methane production. The samples with higher content of manure have gradual increase in the methane production rate at initial stage. But, the samples with higher SSO content have sudden increase in the methane production in the initial stage. For all the different mixtures the maximum methane production occurred after 6 days.

Figure 10 shows the maximum methane production rate for the different mixing ratios. The samples with the ratio of $M: S=1: 9$ and $M: S=3: 7$ have the maximum methane production rate of $46 \mathrm{~mL} /$ day. The sample with mixing ratio of $\mathrm{M}: \mathrm{S}=5: 5$ has the lowest methane production rate of $41 \mathrm{~mL} /$ day among all other samples. As the amount of SSO is more, the methane production rate is higher. By adding manure with the $\mathrm{SSO}$, we can increase the methane production rate.

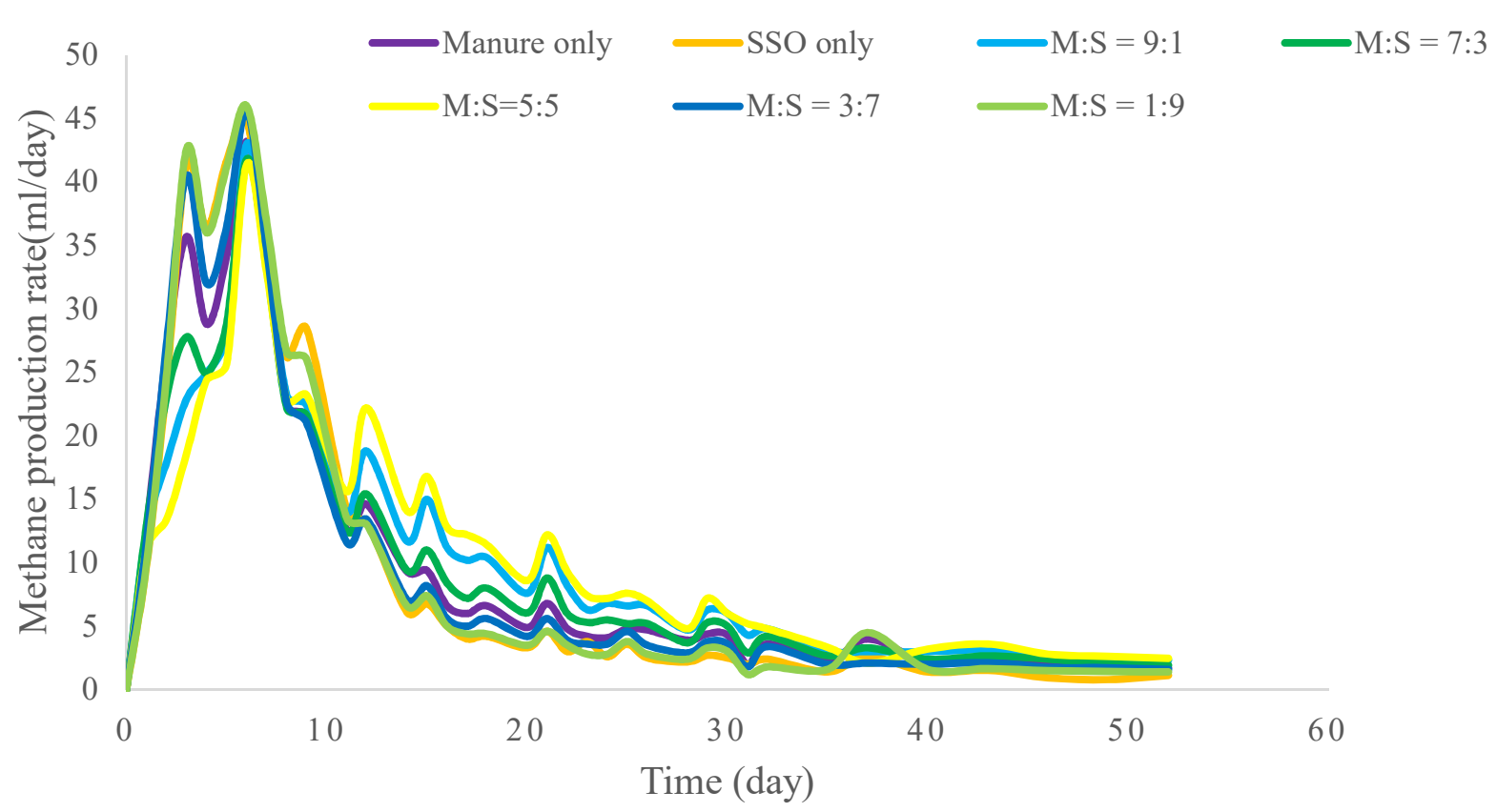

Figure 9. Methane production rate at different mixture ratio 


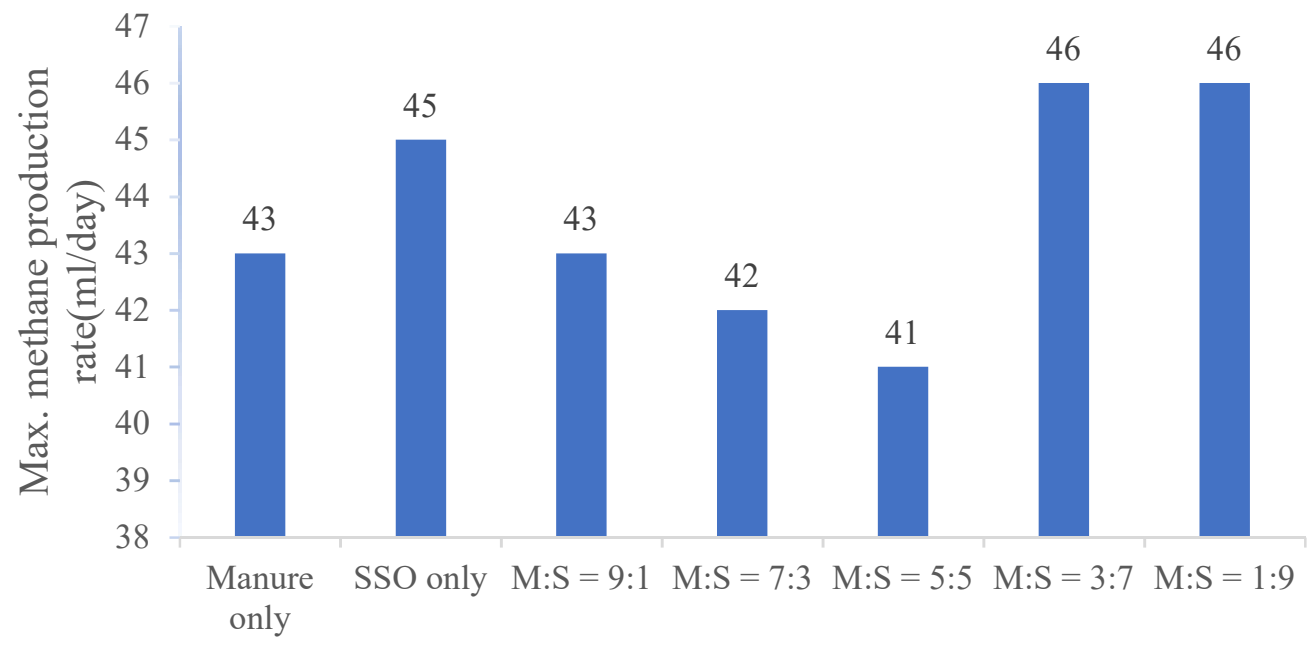

Different mixing ratios

Figure 10. Maximum methane production rate

\subsection{Cumulative methane production}

The cumulative methane production is presented in the figure below. Figure shows the comparison of cumulative methane production at different co-digestion ratios of manure/SSO. The ultimate cumulative methane production of $507 \mathrm{~mL} \mathrm{CH}_{4}$ for $\mathrm{M}: \mathrm{S}=5: 5$, while this value was $453 \mathrm{~mL} \mathrm{CH}_{4}$ for manure and $428 \mathrm{~mL} \mathrm{CH}_{4}$ for $\mathrm{SSO}$ alone.

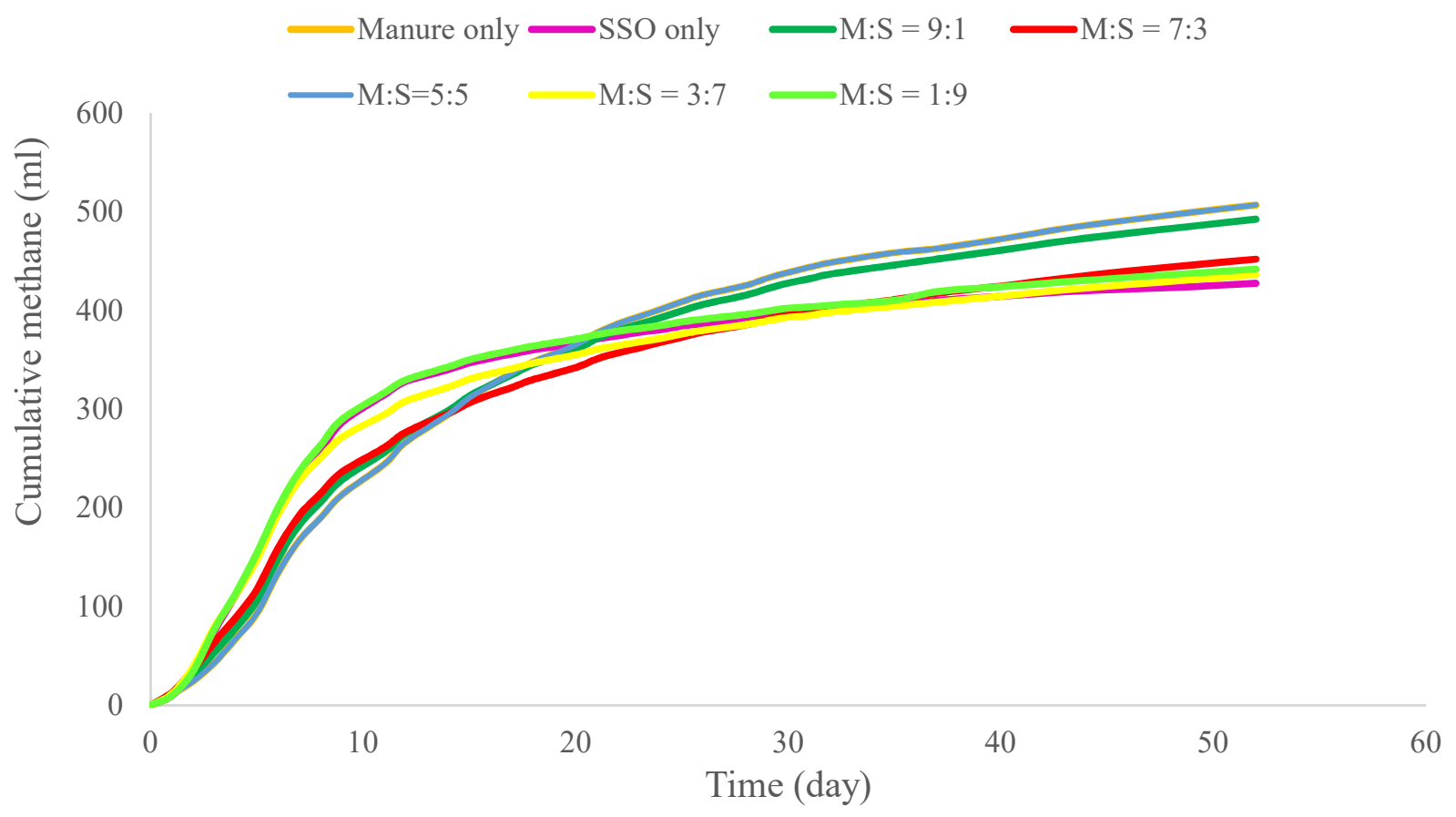

Figure 11. Cumulative methane production at different mixing ratios 


\subsection{Methane yields}

Different types of methane yields were calculated. The following figures shows the methane yields in form of $\mathrm{mL} \mathrm{CH} 4 / \mathrm{mL}$ substrate added, $\mathrm{mL} \mathrm{CH} 4 / \mathrm{g}$ VSS added and $\mathrm{mL} \mathrm{CH} 4 / \mathrm{g}$ TCOD added. Methane yield as $\mathrm{mL} \mathrm{CH} 4 / \mathrm{mL}$ substrate added was lowest for manure only sample. As the amount of SSO added with manure increased the methane yield as $\mathrm{mL} \mathrm{CH} 4 / \mathrm{mL}$ substrate also increased. Same kind of behavior was observed for the methane yield as mLCH4/g VSS added, with the maximum value of $653.58 \mathrm{mLCH} / \mathrm{g}$ VSS added for SSO only sample.

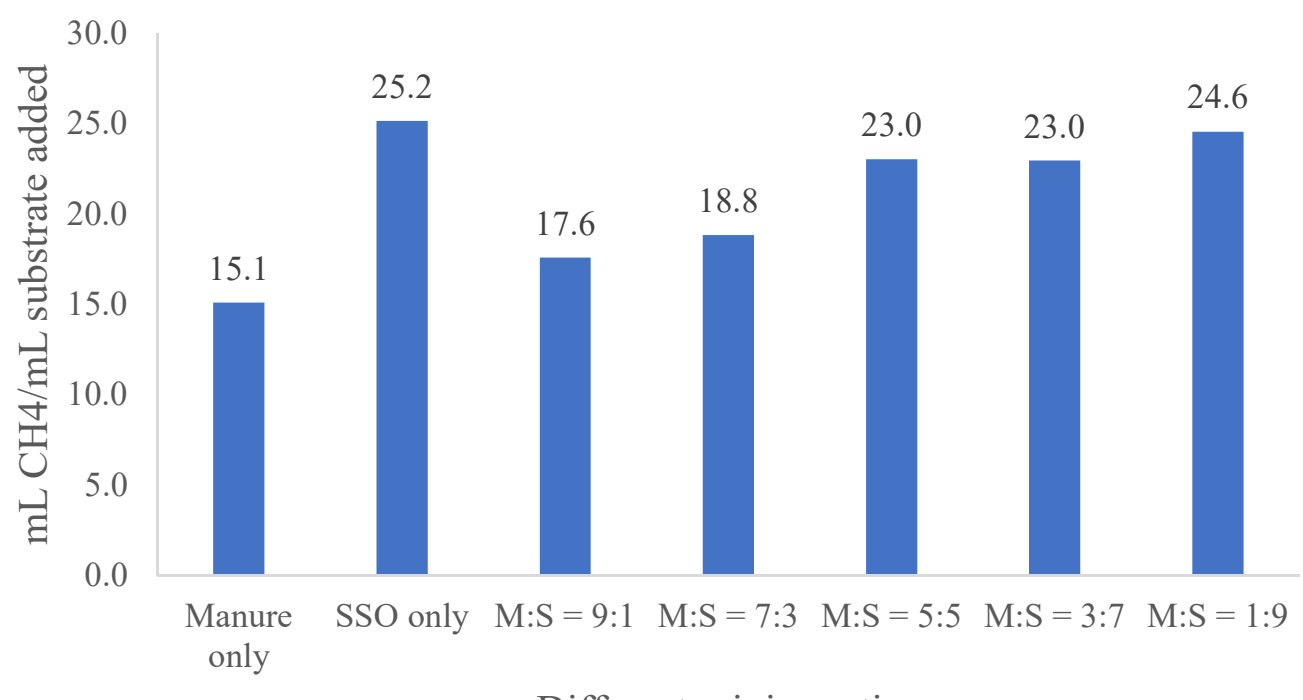

Different mixing ratios

Figure 12. Methane yield ( $\mathrm{mLCH} 4 / \mathrm{mL}$ substrate added) 


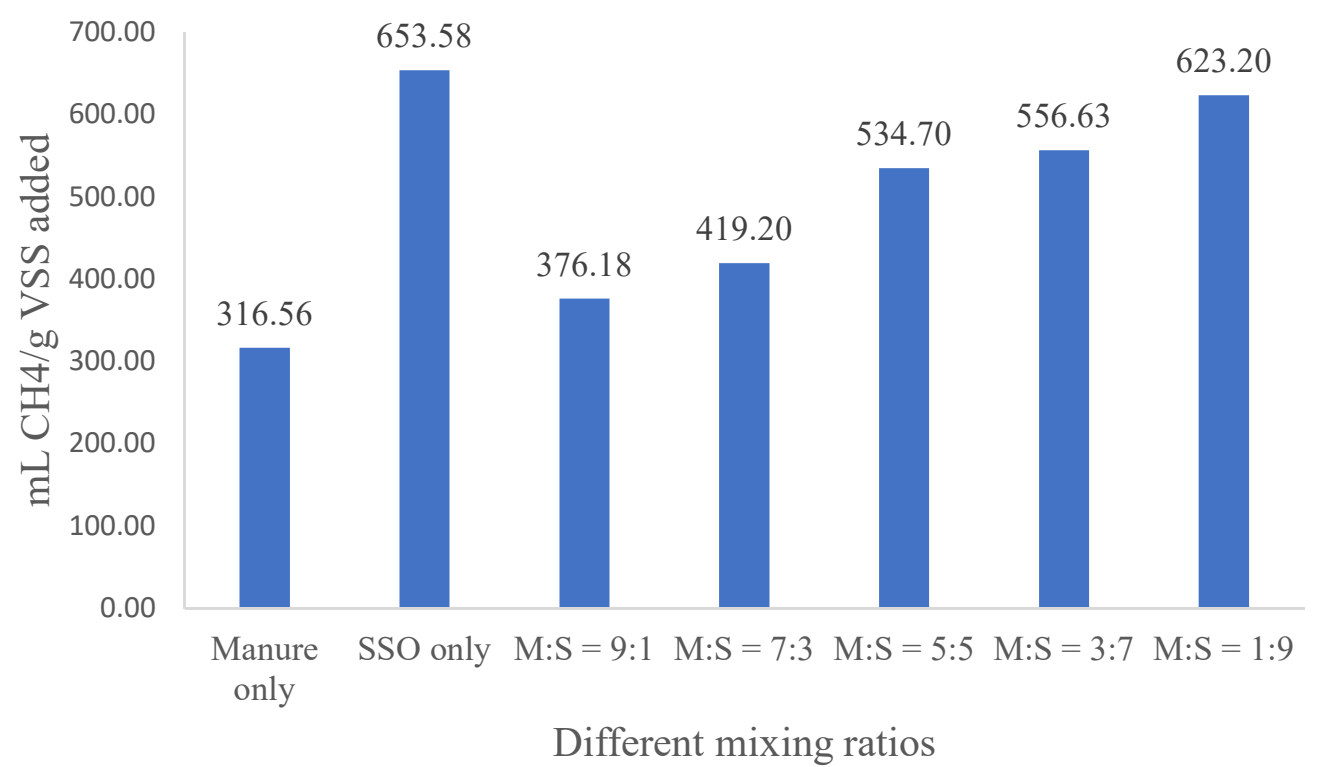

Figure 13. Methane yield (mLCH4/g VSS added)

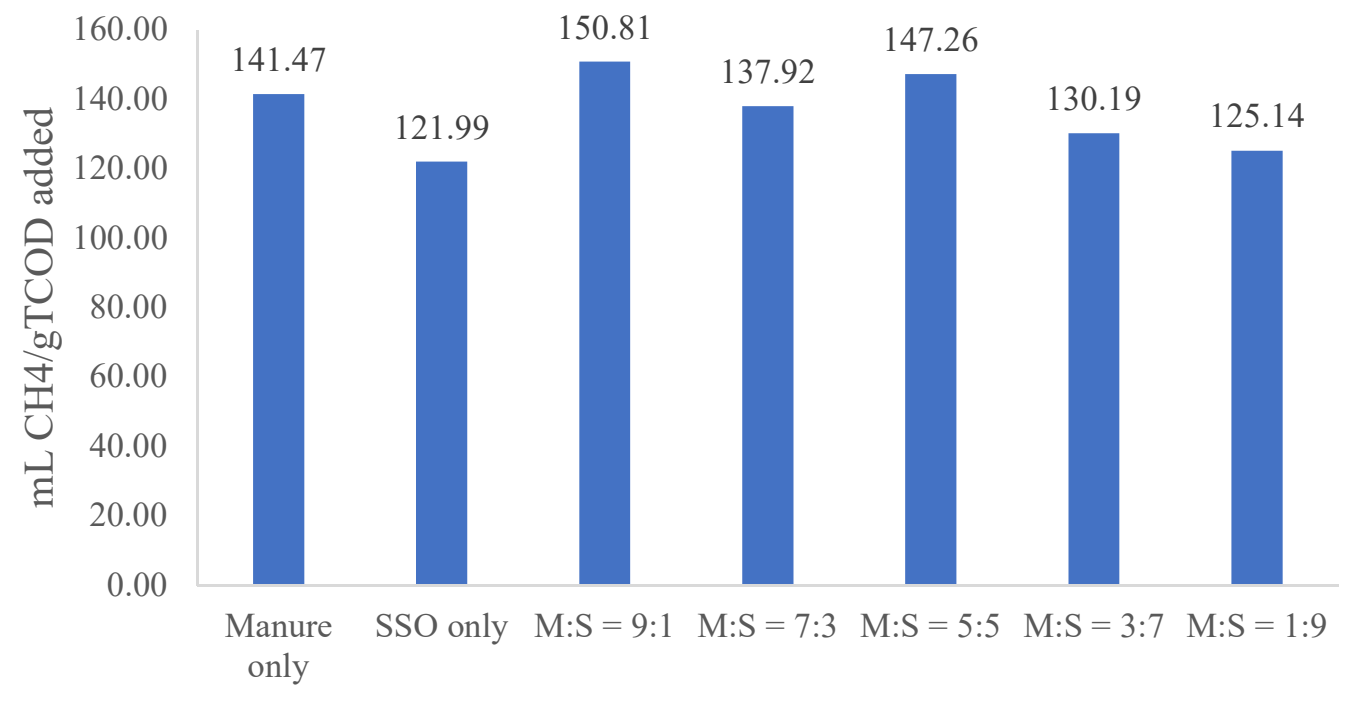

Different mixing ratios

Figure 14. Methane yield (mLCH4/g TCOD added)

The maximum methane yield of about $150 \mathrm{mLCH} 4 / \mathrm{g}$ TCOD added was observed for the manure and SSO ratio of 9:1. As the amount of manure decrease in the sample, that value was also decreased to $125 \mathrm{mLCH} 4 / \mathrm{g}$ TCOD added. 


\subsection{Percentage increase in methane production}

The following table shows the $\%$ increment in the cumulative methane production for the different mixing ratios. For the mixing ratio of $\mathrm{M}: \mathrm{S}=9: 1$, the cumulative methane production was increased to $10 \%$ and for the $\mathrm{M}: \mathrm{S}=5: 5$ it was $15 \%$.

Table 10-\% increase in cumulative methane production

\begin{tabular}{|c|c|c|c|}
\hline Mixture Ratio & $\begin{array}{c}\text { Measured cumulative CH4 } \\
\text { production }\end{array}$ & $\begin{array}{c}\text { Calculated cumulative CH4 } \\
\text { production }\end{array}$ & $\begin{array}{c}\% \text { increase } \\
(\%)\end{array}$ \\
\hline Manure only & 453 & N/A & N/A \\
\hline SSO only & 428 & N/A & N/A \\
\hline $\mathrm{M}: \mathrm{S}=9: 1$ & 493 & 450.9 & 9.3 \\
\hline $\mathrm{M}: \mathrm{S}=7: 3$ & 452 & 445.8 & 1.4 \\
\hline $\mathrm{M}: \mathrm{S}=5: 5$ & 507 & 440.7 & 15.1 \\
\hline $\mathrm{M}: \mathrm{S}=3: 7$ & 436 & 435.6 & 0.1 \\
\hline $\mathrm{M}: \mathrm{S}=1: 9$ & 442 & 430.5 & 2.7 \\
\hline
\end{tabular}




\section{Conclusion}

Co-digestion can result in a significant increase of the bio-methane potential when the substrates mixture is prepared with proper percentages of the different organic substrates to be digested. Codigestion results higher methane yields and improves the quality and quantity of methane content when compared to the single waste digestions. A constant rate for the digestion process can be sustained and it avoids the digester to be underloaded or overloaded. By using co-substrates more gas can be produced and subsequently more electricity will be obtained at only marginal cost. The excess of electricity produced can be utilized to supply the energy demands of waste water treatment avoiding extra cost.

The ultimate cumulative methane production of $507 \mathrm{~mL} \mathrm{CH}_{4}$ for $\mathrm{M}: \mathrm{S}=5: 5$, while this value was $453 \mathrm{~mL} \mathrm{CH}_{4}$ for manure and $428 \mathrm{~mL} \mathrm{CH}_{4}$ for $\mathrm{SSO}$ alone. The ultimate cumulative methane production of $493 \mathrm{~mL}$ was observed for the sample having ratio of $\mathrm{M}: \mathrm{S}=9: 1$. The maximum methane yield of about $150 \mathrm{mLCH} 4 / \mathrm{g}$ TCOD added was observed for the manure and SSO ratio of 9:1. The maximum percentage of increase in the cumulative methane production was about $15 \%$ for the sample having mixing ratio of $\mathrm{M}: \mathrm{S}=5: 5$. 


\section{References}

I. A.O. Adebayo, S. J. (2014). Anaerobic Co-Digestion of Cattle Slurry with Maize Stalk at Mesophilic Temperature. American Journal of Engineering Research (AJER), 80-88.

II. G. Esposito, L. F. (2012). Anaerobic co-digestion of organic wastes. Rev Environ Sci Biotechnol. (Springer).

III. Kelleher, \& Robins. (2013). Canadian Biogas Study.

IV. Kennedy, N. (2015). ON-FARM CO-DIGESTION OF DAIRY MANURE WITH HIGH ENERGY ORGANICS. Whashington: Whashington State University Extension.

V. M. Elsayed, Y. A. (2015). Methane Production By Anaerobic Co-Digestion Of Sewage Sludge And Wheat Straw Under Mesophilic Conditions. INTERNATIONAL JOURNAL OF SCIENTIFIC \& TECHNOLOGY RESEARCH.

VI. Richard Wickham, B. G. (2016). Biomethane potential evaluation of co-digestion of sewage sludge and organic wastes. International Journal of Biodeterioration and Biodegradation.

VII. Richard Wickham, B. G. (2016). Biomethane potential evaluation of co-digestion of sewage sludge and organic wastes. International Journal of Biodeterioration and Biodegradation.

VIII. Steffen, R., Szolar, O., \& Braun, R. (1998, September-30). Feedstocks for Anaerobic Digestion.

IX. Wilkie, A. C. (2005). Anaerobic Digestion of Dairy Manure: Design and Process Considerations. Dairy Manure Management Conference, NRAES-176, (pp. 301-312). Ithaca, NY. 


\section{Glossary}

$\begin{array}{ll}\text { AD } & \text { Anaerobic Digestion } \\ \text { AcoD } & \text { Anaerobic Co-digestion } \\ \text { SSO } & \text { Source Separated Organics } \\ \text { TCOD } & \text { Total Chemical Oxygen Demand } \\ \text { VSS } & \text { Volatile Suspended Solid } \\ \text { BMP } & \text { Biochemical Methane Potential } \\ \text { COD } & \text { Chemical Oxygen Demand } \\ \text { K } & \text { Potassium } \\ \text { N } & \text { Nitrogen } \\ \text { P } & \text { Phosphorus } \\ \text { pH } & \text { Power of Hydrogen }\end{array}$

